\title{
Intertemporal diversification of sub-sovereign debt
}

\author{
David Knezevic ${ }^{1,2}$
}

Received: 19 December 2017 / Accepted: 24 July 2018 / Published online: 2 August 2018 (c) The Author(s) 2018

\begin{abstract}
This paper presents a comprehensive empirical analysis of the debt maturity structure of the Swedish municipal sector. The Swedish municipal debt portfolio is characterized by a short maturity structure and an asset-liability mismatch that poses potentially severe roll-over risk. The 2008-2009 financial crisis manifested as a liquidity shock to the sector that highlighted the dangers of short-term funding strategies in conjunction with low levels of intertemporal diversification. In this study we analyze to what extent this led to a change of intertemporal diversification. Based on a unique contractlevel monthly data set of municipal loans issued by Kommuninvest of Sweden from January 1997 to June 2016, we construct and estimate a range of dispersion and moment measures to capture the change of various distributional characteristics of the maturity structure. These measures are used as dependent variables in fixed-effects models together with a number of control variables to estimate the effect of the debtcrisis liquidity shock. The main finding is that the crisis did affect the diversification, but not in a persistent way. A possible explanation is that the municipalities found that Kommuninvest through jointly guaranteed lending was able to function as a lender of last resort and thereby mitigates the roll-over risk. It is also found that fiscal and financial properties such as debt-to-tax base ratio, tax base volatility and per capita income are associated with the characteristics of the debt maturity structure of Swedish municipalities, as well as macroeconomic factors such as the term structure of interest rates.
\end{abstract}

Keywords Short-term debt · Term structure $\cdot$ Liquidity risk · Roll-over risk · Asset-liability management $\cdot$ Debt maturity $\cdot$ Financial crisis

This paper has benefited from comments by two anonymous referees, Martin Andersson, Pär Österholm, Lars Hultkrantz, Martin Nordström, Niclas Krüger, Mattias Bokenblom, Erik Törnblom and seminar participants at Örebro University, the 3rd International Conference in Applied Macro and Empirical Finance in Thessaloniki and the 2017 Swedish Graduate Program in Economics (SWEGPEC) annual workshop in Stockholm.

$凶 \quad$ David Knezevic

david.knezevic@oru.se; david.knezevic@kommuninvest.se

Extended author information available on the last page of the article 
JEL Classification G20 · G23

\section{Introduction}

In retrospect, the recent global financial crisis highlighted the dangers of high levels of short-term debt in states of illiquid credit markets. As emphasized by the Basel III regulations, prudent asset-liability management is of high importance in mitigating the effects of market liquidity shocks (Basel Committee on Banking Supervision 2014). If a substantially large share of a debt portfolio matures in a period of illiquidity, it can result in incomplete investment projects, insolvency and potentially bankruptcy (Diamond and Dybvig 1983; Diamond 2007). This is referred to as roll-over risk which highlights the importance of a debt maturity structure characterized by intertemporal diversification. Intertemporal diversification is a way to hedge against liquidity risk when asset-liability matching is not possible. In this context diversification is synonymous with dispersion of debt maturity.

The financing strategy of Swedish municipalities is characterized by a reliance on a high degree of short-term debt which in turn is used to fund significantly longer investment projects, thereby introducing a mismatch between assets and liabilities. By contemporary knowledge and experience it is obvious that this strategy poses some severe risks. Nevertheless, short-term financing has posed little cause for concern due to the historical stability of the Swedish financial sector. This all changed during the 2008-2009 financial crisis which manifested as a liquidity shock to the Swedish financial system. Financing became unavailable due to increased risk aversion of commercial banks. Maturing debt had to be repaid and the risky practices of the municipal sector were brought to light. This forced municipalities to utilize other financing channels. One of these was Kommuninvest of Sweden) - a collectively, municipally owned credit institution, also sometimes referred to as a Local Government Funding Agency (LGFA) — which due to its unique business model could finance the sector's investment needs. The purpose of this paper is to investigate how Swedish municipalities reacted to the 2008-2009 financial crisis in terms of debt management and if the adjustment was persistent for the post-crisis period. Although the effect of the crisis was dampened by the aid of Kommuninvest, it is important to realize that the risks are not erased, simply transferred, and that future crises may be more severe. Identifying the risks associated with debt is particularly important in the case of Swedish municipalities since a majority of the Swedish welfare system is funded at the local level and is dependent on a stable municipal sector.

This paper contributes to the existing literature in three ways. First, by further building on the findings of Missale and Blanchard (1994), Barro (1995, 1997) and Cestau (2010). It is shown that higher moments are necessary complements to the average time to maturity for conducting a sufficient assessment of the risks related to debt, something which has been overlooked by previous research. This is done by proposing multiple moment and dispersion measures so as to capture the different characteristics of the debt maturity structure. To my knowledge, such measures have not been previously proposed for describing distributional characteristics of debt. Second, by conducting an in-depth investigation of the effects of the 2008-2009 financial 
crisis on the Swedish municipal sectors debt portfolios and financing strategies. This is done by employing a unique data set of contract-level data of all loans issued by Kommuninvest of Sweden for the period 1998-2016. Third, by showing that the financial crisis induced Swedish municipalities to increase intertemporal diversification and the average time to maturity, but that the effect was not persistent. ${ }^{1}$ The financial crisis was manifested as a systemic liquidity shock which exacerbated the idiosyncratic rollover risk of the municipalities. Thus, the financial crisis is an event which should have had a significant impact on the measures. It is also shown that fiscal characteristics such as the tax base volatility, debt-to-tax base ratio, per capita income and financial ratios have explanatory value for Swedish municipalities' choice of maturity structure. Macroeconomic factors such as interest rates and market liquidity are consistently statistically significant. In addition, municipalities are less inclined to take on long-term debt when close to an election.

Multiple dispersion measures are suggested as compliments to the average time to maturity. These measures act as dependent variables in fixed-effects models where the municipal individual effects are controlled for and a wide range of macroeconomic time series identification variables are included so as to capture and disentangle the different time-varying effects. This empirical framework is appropriate when assessing refinancing risk in sectors for which typical asset-liability measures are not suited, such as public entities and governments.

This analysis should be of direct interest to countries which have municipal credit markets similar to that of Sweden. Countries that currently have established LGFAs are Denmark, Canada, Finland, France, the Netherlands, New Zealand, Norway and Switzerland. In contrast, US municipalities rely almost exclusively on direct funding by issuing securities on the capital markets and are therefore more restricted in their choice of term, both due to market powers ${ }^{2}$ but also due to fiscal regulation. The broader framework of managing and evaluating risk associated with debt is highly relevant for both governments and corporations.

The remainder of the paper is organized as follows. In Sect. 2, terminology and previous research is presented. Section 3 gives an overview of the Swedish municipal sector and Kommuninvest of Sweden. Section 4 presents the main data set and the construction of the moment and intertemporal diversification measures. Section 5 presents the main regression models and the explanatory variables. In Sect. 6, the results are presented and discussed. We also conduct some sensitivity analysis. Finally, Sect. 7 concludes.

\footnotetext{
1 In contrast, when investigating the effect of the financial crisis on corporate debt González (2015) finds the opposite effect that the share of short term debt increased during the crisis. This discrepency most likely has to do with the differences between the different credit markets where Swedish municipalities are less restricted in the type of credit they undertake. Shen (2017) models optimal government bond duration for emerging economies using a DSGE framework and concludes that a bond duration of seven qurters maximized welfare. A drawback of this approach is that the agent cannot hold multiple bonds of different durations simultaniously. Thus, neither of these papers account for debt maturity dispersion and intertemporal diversification.

2 Kommuninvest has historically never restricted credit at any term or to any member and all members face a similar price structure. Thus, credit market supply and price discrimination due to difference in creditworthiness have a relatively small impact on the types of debt undertaken by Swedish municipalities.
} 


\section{Background}

The concepts of roll-over risk, asset-liability management and intertemporal diversification are tightly intertwined. Asset-liability management and intertemporal diversification are financial frameworks for risk mitigation, including roll-over risk. Following is a brief overview of these concepts and a review of the previous literature.

\subsection{Terminology}

The theorem on the value of corporate capital presented in the seminal papers by Modigliani and Miller $(1958,1963)$ states that in frictionless markets with the absence of taxes and bankruptcy costs the value of assets is unaffected by the capital structure of the firm. By extension, the costs associated with government debt will ultimately be covered by the taxpayers and the structure of government debt becomes irrelevant (Cochrane 2015). Taking the theorem to reality, it is obvious that some assumptions fail though and, conversely, that the structure of debt is relevant. Roll-over risk arises when a debt contract matures and then is renewed, or rolled over. Depending on the contract, roll-over risk can incorporate many types of risks such as uncertainty in the exchange rate or other foreign market frictions. The roll-over risk of a debt contract issued on the domestic market, in the domestic currency, can be decomposed into at least two parts. First, the risk that interest rates will be substantially higher at maturity relative to the initial debt contract, resulting in increased costs when the debt is refinanced. Second and arguably more hazardous, the risk that credit markets are illiquid at maturity, in which case refinancing becomes inaccessible and full repayment of the debt is required. Thus, high reliance on rolling over short-term debt increases the risk that the debt matures in a period when banks and capital markets are facing liquidity difficulties. Brennan and Schwartz (1978) present the first quantitative effort in modeling optimal leverage. They argue that bankruptcy is triggered when the firm's asset value falls to the debt's principal value. Leland (1994) argues that this type of bankruptcy is not the primary type observed in the economy and suggests that an additional bankruptcy trigger would be when firms are unable to raise sufficient funds to meet their current debt obligations. To derive a closed-form solution to the analytical model Leland assumes that debt is time independent, which he argues is equivalent to a debt contract being rolled over indefinitely. Modigliani and Miller (1958), Merton (1973) and Black and Cox (1976) all treat debt as having infinite maturity in different frameworks.

Asset-liability management (ALM) is the process of matching the cash flows of assets and liabilities in an effort to reduce risks. It is argued that ALM was developed in the late 1970s and early 1980s as a response to the heavy regulations imposed on US insurance companies (Financial Accounting Standards Board 1985; Ryan 2013). The time to maturity of debt is matched with the horizon of the investment; thus, there is no reliance on the rolling over of debt. This process is usually applied by banks, insurance companies and pension funds where both the asset and liabilities are primarily made up of financial securities. This makes matching more manageable since future cash flows of both are well defined and easily modifiable. For other institutions such as 
municipalities ALM becomes potentially more difficult. Swedish municipalities are prohibited to collateralize assets to live up to their debt obligations and by their nature public goods and services are illiquid which further complicates matching assets and liabilities. Additionally, Cochrane (2015) argues that although some of government assets are tangible, the bulk of assets are made up of the present value of an infinite stream of future tax revenues that are even more difficult to predict and internalize. For these institutions intertemporal diversification becomes a more suitable, albeit blunter tool for hedging against liquidity risk.

In theory, intertemporal diversification of a debt portfolio is the process of reducing the amount of debt maturing at each given point in time, given a set amount of debt. In practice, this implies taking on a large number of smaller loans and choosing a more disperse maturity structure. In terms of sector-wide liquidity shocks diversification of the maturity structure reduces the risk that a substantial share of the debt matures during each period, such that repayment can be covered without the need of refinancing. Thus, intertemporal diversification is a way to hedge against the systemic risk, i.e., a market-wide liquidity risk. Therefore, measures which describe the distributional characteristics of the debt maturity structure of a portfolio are also useful tools for evaluating the risks of said portfolio.

The strategy of intertemporal diversification is nothing new from an investment perspective. Dollar-cost averaging is an investment strategy that states that many small stock purchases at fixed amounts, with fixed time intervals, are beneficial from a risk mitigation perspective over a lump sum purchase. If stock prices are high, the fixed amount will buy the investor fewer stocks and vice versa. Dollar-cost averaging results in potentially lower returns compared to lump sum purchases but arguably comes at a lower downside risk. The criticism of dollar-cost averaging is based on the fact that stock markets historically have had a long-run upward trend, and therefore, it is optimal to purchase earlier rather than later. In the context of debt management, there is no obvious reason to assume that liquidity has a long-run upward trend. Thus, the criticism of dollar-cost averaging does not carry over to the process of intertemporal diversification of debt.

\subsection{Literature review}

The optimal choice of debt maturity for corporations is a subject which has been addressed by numerous authors in the field of corporate finance, specifically contract theory. Early work by Myers (1977) suggests that short-term debt is optimal because long-term debt may lead to future underinvestment due to debt-holder claims on future cash flow. ${ }^{3}$ Unfortunately, this research is proven inapplicable on the subject of government debt maturity. The reason is that the intrinsic conflict of interest between debt and equity holders which gives rise to the debt overhang in the model is not present. This is not to say that there is no debt overhang problem present. One can easily see that high leverage and public spending by the current generation can pose debt overhang on future generations. The difference is that equity holders in the Myers

\footnotetext{
3 More recent studies on the debt overhang problem are Philippon and Schnabl (2009), Diamond and Rajan (2011) and Diamond and He (2014).
} 
model have the power to affect the amount of leverage that a firm undertakes while future generations have no power over the debt structure and public spending of the current generation. Therefore, we instead turn to empirical studies that focus on the debt maturity structure of sovereign states.

Some authors try to rationalize governments' choices of debt maturity and their findings will be of use when constructing the models later in this paper. Missale and Blanchard (1994) investigate the evolution of the term structure of government debt of the OECD countries over a 30-year period from 1960 to 1990 . They observe that term and amount of outstanding debt generally does not seem to have a strong relationship. However, when focusing on countries with debt-to-GNP ratios close to $100 \%$ the term of new debt is inversely related to the amount of outstanding debt. They conclude that in order to maintain the credibility of its anti-inflation stance the government may need to decrease the maturity of the debt as the amount of outstanding debt increases. Arguably, the explanation that is given by Missale and Blanchard is not related to the study of local governments since monetary policy is a central government issue. However, there could be multiple dimensions to this relationship not highlighted by the authors. One can assume that high levels of leverage can constrain the budget of the local government. In an effort to relieve this constraint by reducing the cost of borrowing the local government may choose to borrow and refinance at a shorter maturity.

Another explanation is given by Barro $(1995,1997)$ who argues that the type of debt that the government issues is of importance if there is uncertainty regarding real interest rates, level of public outlay and the tax base (aggregate consumption and GDP). The government may choose an appropriate maturity structure so as to smooth tax rates over different states of nature. For instance, the maturity structure of the debt can be designed so as to insulate the government's financing costs from shifts in real interest rates. This implies that local governments with a volatile tax base may choose to diversify its maturity structure or borrow at a longer maturity. A long-term maturity structure gives leeway such that debt can be repaid prior to maturity at hightax-revenue states of nature while new debt is undertaken in low-tax-revenue states. By this strategy the maturity may retain its long-term structure.

A more recent paper by Cestau (2010) finds empirical evidence for a U-shaped relationship between the share of short-term debt issued by sovereign states and the per capita income level. This suggests that countries with high and low income levels have on average a larger share of short-term debt compared to countries with medium income levels. The author argues that high-income countries, due to their creditworthiness, are less likely to face illiquidity and are therefore less concerned as regards to roll-over risk. Medium-income countries face a higher probability of market illiquidity and attempt to hedge against this risk by a larger share of long-term debt. Finally, low-income countries prefer to avoid the additional costs of long-term debt. Similarly to Barro, Cestau points out that the income of the population and by extension the tax revenues are of importance when the government chooses debt structure. Where they differ is that Cestau implies that the level of income is of primary importance, whereas Barro emphasizes the importance of the level of uncertainty of income.

Intertemporal diversification is a way to hedge against market-wide illiquidity, whereas diversification of creditors and financing channels is used when diversifying 
against idiosyncratic risks intrinsic to the creditors. Thierfelder (2008) argues that high-quality firms in addition to direct funding by debt securities utilize a backup line of credit in case of market illiquidity. Thus, credit institutions take the role of "lenders of last resort." This can also be observed in the Swedish municipal sector where large municipalities that have access to direct funding by issuing debt securities also utilize other financing channels. Similarly, Gate and Strahan (2006) show that in times of market illiquidity credit institutions experience funding inflows, thus acting as safe havens. They argue that it is the ability to hedge against market-wide liquidity shocks that allows these institutions to supply credit even under these circumstances. A similar behavior could be observed for the Swedish municipal sector during the 2008-2009 financial crisis when Kommuninvest became the "lender of last resort."

Finally, the effect of the political election cycle is discussed. The Swedish local governments, like all democratically elected governments, are faced with the political realities of running for office and potentially staying in office over multiple cycles. As shown by Nordhaus (1975), a sufficient level of current social investments is necessary to raise consumption for the next period, i.e., after the up-and-coming election. However, from the electorate's point of view social investments are costly due to increased taxation and/or inflation. Therefore, social investments will be at a sub-optimal level and in equilibrium the social rate of return on public investments will be higher than for private investments due to the democratic myopia. Nordhaus also observes that there is a predictable pattern in policy over the incumbent's term in office, starting with relative austerity and ending with the potlatch right before the election. In terms of local governments the conclusions do not perfectly follow. For instance, the individual local government policy effect on inflation is much less substantial than that of the central government. Small municipalities can be viewed as price takers that have no effect on inflation. Thus, increasing local public investments financed through debt does not have any obvious macroeconomic consumption costs from the perspective of the electorate. In the theoretical model the perfect democracy will make decisions that are against the interests of future generations. Social investments can be financed through new debt with no added cost in terms of consumption, and the risk of refinancing can be avoided by pushing repayment onto future generations. Therefore, it is expected that more long-term debt will be undertaken close to the election so as to supply the electorate with a more diversified basket of public goods and improve the public perception of the incumbent. This comes with an added cost in terms of a reduction of expected future consumption. However, although this kind of strategic maneuvering is not specifically prohibited in the legislation, it could be at odds with the overarching aim of the Swedish Local Government Act, specifically the principles of sound financial management and non-speculative action. Thus, this could deter such strategies from being applied. The Swedish Local Government Act is discussed further in next section. 
Table 1 Areas of responsibility categorized by level of government

\begin{tabular}{|c|c|c|c|}
\hline \multirow[t]{2}{*}{ Level of government } & \multirow[t]{2}{*}{ Comprising of } & \multicolumn{2}{|l|}{ Areas of responsibilities } \\
\hline & & Compulsory & Voluntary \\
\hline \multirow[t]{3}{*}{ Regional level } & 21 Counties (Landsting) & Health and medical care & Culture \\
\hline & & Dental care & Education \\
\hline & & Public transport & Tourism \\
\hline \multirow[t]{11}{*}{ Local level } & $\begin{array}{l}290 \text { Municipalities } \\
\text { (Kommuner) }\end{array}$ & Social services & Leisure and culture \\
\hline & & Education & Technical services \\
\hline & & $\begin{array}{l}\text { Building/planning } \\
\text { issues }\end{array}$ & Energy supply \\
\hline & & $\begin{array}{l}\text { Environmental/health } \\
\text { protection }\end{array}$ & Streets/roads \\
\hline & & Waste/sanitation & Housing construction \\
\hline & & Water/sewage & Business development \\
\hline & & Emergency services & \\
\hline & & Libraries & \\
\hline & & $\begin{array}{l}\text { Crisis contingency } \\
\text { planning }\end{array}$ & \\
\hline & & Housing provision & \\
\hline & & Public transport & \\
\hline
\end{tabular}

Public transport is a joint responsibility between the local and regional governments due to the fact that public transportation often crosses municipal borders

\section{Institutional framework}

\subsection{Swedish municipalities}

The Swedish political system is divided into three levels of government: local, regional and national. The local government acts on a municipal level and is in closest proximity to the citizens. The municipal assembly is its highest decision-making entity and has final authority regarding questions of a financial nature such as budget, taxes, fees and liabilities. The municipal assembly is elected by the citizens every fourth year at the same time as the parliamentary elections. The areas of responsibility differ between the three tiers of government. Table 1 gives a detailed overview of responsibilities for the local and regional levels; the central government is omitted since Kommuninvest only issues loans to local and regional governments. The governments can choose freely how to supply their services, either by employing private companies or by subsidiaries. A majority of companies owned by local governments operate in capital intensive sectors, such as housing and energy. The time horizon of Swedish municipal investments is on average approximately 20 years (Kommuninvest (2017)).

The Swedish sub-sovereign governments have the constitutional right to selfgovernance with free right of decision-making in the context of their responsibilities. Swedish sub-nationals are required under the Swedish Local Government Act (Kom- 
munallag 1991: 900) to operate in accordance with sound financial management. The rules laid out by the act are exercised by municipalities, counties and their subsidiaries. It entails setting up operational and financial goals and guidelines for the organization and the economic use of resources in both the short-and long-terms. The use of debt or the collateralization of assets to finance its operations is not considered consistent with sound financial management. Therefore, liabilities are only to be used for the funding of investments. The Local Government Act also states that sub-nationals are prohibited from partaking in activities of a speculative nature. A sub-sovereign government's main purpose is supplying its residents with public services rather than profit seeking. However, in line with the Local Government Act and the principle of sound financial management a sub-sovereign government must present a budget surplus at the end of each fiscal year.

The freedom enjoyed by Swedish sub-nationals does not imply the freedom to default on debt. In 1992 the municipality of Haninge was unable to cover the unforeseen costs of one of its subsidiaries and came close to bankruptcy. The ordeal was resolved by a government bail-out of the municipality and the acquirement of the subsidiary. This was seen as a loan that the municipality of Haninge had to amortize. The government bail-out possibly sent a signal to creditors and investors that Swedish municipalities cannot go into bankruptcy. In addition, a Swedish district court decision stated that a municipality cannot cease to exist and that only the parliament can decide on the merger of two or more municipalities, in which case the assets and liabilities of one carries over to the others. Sub-sovereign governments are liable for all obligations they enter into, with all their tax power and their total assets. Swedish municipalities are autonomous and thus have the right to levy taxes and to set local fiscal policies. The amount and consistency of tax revenues are important factors that dictate the level of risk acceptance for the individual municipality.

In addition, a system for local governmental fiscal equalization has been implemented to ensure that local governments have equal basic conditions for providing their residents with public services. The system, one for municipalities and one for counties, is comprised of an income equalization and a cost equalization part. Income equalization is state-funded in the form of grants, and its primary purpose is to even out differences in the tax base of the local governments. The cost equalizations primary purpose is to even out differences in structural costs. The local governments with unfavorable cost structure are paid a cost equalization grant, while those with a favorable structure pay a charge. Both tax revenues and state grants are allowed to be used to cover both operational costs and expenditures for investments purposes. Equalization somewhat diminishes the effect of taxes on the risk acceptance of municipalities.

Swedish municipalities rely on issuing debt or taking on credit to finance large investments. Some of the larger actors have the option of issuing debt securities directly on the financial markets. Smaller municipalities usually lack the necessary investment volumes of their larger counterparts but can collectively establish in-house banks that issue debt securities on their behalf with the intent of pooling risks, thus reducing credit spreads and interest costs. The current main source of financing is loans from Kommuninvest of Sweden. 


\subsection{Kommuninvest of Sweden}

Kommuninvest of Sweden AB is a credit institution owned by Kommuninvest economic association. Its mission is to supply the Swedish municipalities, counties and their subsidiaries with sustainable, reliable and cost-efficient financing. All members face a common, non-negotiable price structure which is set by the 3-month STIBOR spot and swap rates in addition to a Kommuninvest specific margin which is more or less constant over the whole term structure. In addition, Kommuninvest has historically never restricted its lending for any of its products in contrast to commercial banks that may periodically refuse to finance loans of certain maturities. Membership is open but not obligatory to all Swedish municipalities and counties. As of June 2016 there are 274 member municipalities (out of 290 possible) and 11 member counties (out of 21 possible) (Kommuninvest 2017). All commitments entered into by Kommuninvest of Sweden are jointly guaranteed by its members. Each member contributes participation-capital based on a population model and has one vote regardless of size or contribution. Members decide on the overall direction of the organization and bear the ultimate responsibility. Even though the legal status of an economic association under Swedish law does not require the conformation to the Local Government Act, Kommuninvest has self-imposed to follow these regulations. Thus, for all intents and purposes Kommuninvest is viewed as a municipal subsidiary.

The organizational structure and pooling of risks is of importance in terms of the institution's creditworthiness. Since 2002 Kommuninvest has received the highest credit rating by Moody's rating house (Aaa) and likewise from Standard and Poor's since 2006 (AAA). Another important factor is the organization's funding strategy. According to its stated directive funding must exceed its lending by at least 15 and at most $35 \%$. This excess liquidity is invested non-speculatively under active management with a low-risk profile so as to abide by the Local Government Act which prohibits financial speculation and requires sound financial management. The purpose of the liquidity portfolio is to be able to supply the sector with credit even in times of market illiquidity. Funding is relatively well diversified in terms of product diversity, maturity structure and issuing region. Main issuing regions are Sweden, Europe, USA, Australia and Japan. In addition, Kommuninvest is a member of Sveriges Riksbank's RIX system for large payments (Sveriges Riksbank 2017a, b). This allows for the intraday lending in case of illiquidity.

The commercial banks have lost a large part of their market share over recent years whereas direct lending and financing through Kommuninvest have increased in relative terms. The evolution of the market share divided between the three financing sources is depicted in Fig. 1.

As of 2012 Kommuninvest is the largest financing channel of municipalities and counties in Sweden. As shown in Fig. 6 in "Appendix" there was a substantial inflow of new Kommuninvest members during the financial crisis, in particular in the year 2009 when 24 municipalities joined the organization. In 200814 new members joined. Comparing the 2-year average shows that the number of new members joining the organization was at its peak during the financial crisis. 


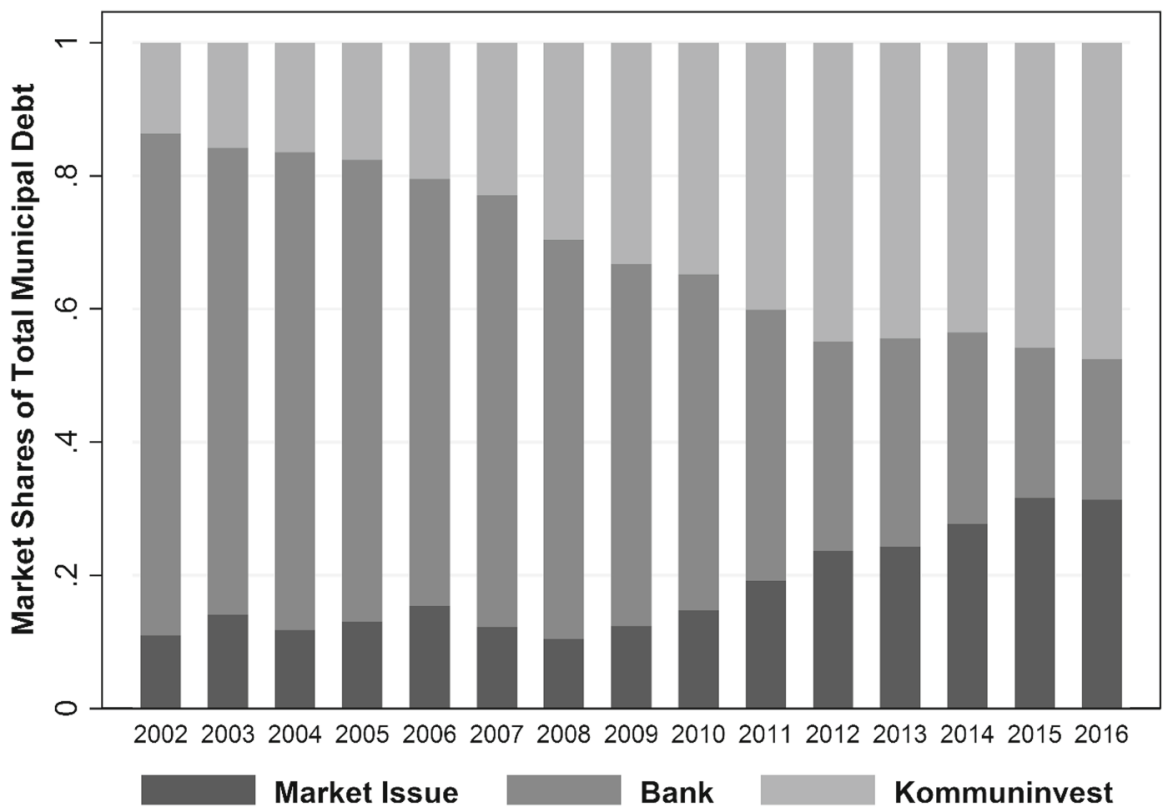

Fig. 1 Evolution of market shares from 2002 to 2016

\section{Data}

A unique data set is provided by Kommuninvest of Sweden. This is comprised of detailed contract-level data for all issued Kommuninvest loans for the period January 1998 to June 2016, for 274 out of 290 municipalities.

A monthly time series for each loan is generated over a 20-year period from January 1998 to June 2016. By using the contracted start and maturity dates the time to maturity for each loan is calculated for each month of the time series and the data set is reconstructed to a panel structure. It is this generated panel data set which will be used for the main analysis. The time to maturity of all active loans, for each month, is used to calculate the moment and dispersion measures of the debt portfolios presented later in this section. The panel data are unbalanced since the number of municipalities present in the data increases over time, from an initial 84 in 1998 to 274 for June 2016.

Perpetual loans are automatically rolled over and have no set maturity date. The interest rate of a perpetual loan with a 3-month STIBOR indexation is reset every third month at the interest reset date. These loans are cancelable by both debtor and creditor and therefor also subject to roll-over risk. The maturity date is only known ex-post cancelation. For this reason perpetual loans are treated differently to standard loans in the time to maturity calculations. By setting the maturity date equal to the next reset date the time to maturity of the loan would initially take the value 3 and decline to 0 during the three following months. At the end of this period if the loan is not canceled, its time to maturity would be reset to 3 again and would oscillate around 0.125 years $\left(\frac{3}{12 * 2}\right)$ but not maturing until being called by either party. By setting the 
Table 2 Issued Loans by Type, June 2016

\begin{tabular}{lcccc}
\hline Types & $N$ & $\begin{array}{c}\text { Sum principal } \\
(\text { million SEK) }\end{array}$ & Share (\%) & Sum principal/N \\
\hline All loans & 5737 & $279,070.97$ & 100.00 & 48.64 \\
Standard loans & 5543 & $274,700.14$ & 98.43 & 49.56 \\
Perpetual loans & 194 & 4370.82 & 1.57 & 22.53 \\
\hline
\end{tabular}

time to maturity equal to 0.125 years (half of the time to interest reset) any such small and redundant variations will be removed (Table 2).

There are six types of perpetual loans when categorizing by time to reset. KI-rate loans are a special kind of product where interest is linked to Kommuninvest's debt security issues; these products have 60 days of time to reset. A few loans are indexed by the Swedish 1-day or 1-month REPO rate. Finally, a majority of perpetual loans are STIBOR-indexed with 3, 6 or 12 months of time to reset.

In recent years Swedish municipalities have to a greater extent moved away from financing by bank loans to issuing debt securities and loans from Kommuninvest. Since 2012 loans from Kommuninvest have been the sector's main financing channel with an approximately $44.9 \%$ market share. Preliminary numbers indicate that $48.3 \%$ of the Swedish municipal debt is financed by Kommuninvest for the year 2016.

Figure 2 illustrates the share of Kommuninvest debt for each of the 290 municipal debt portfolios in falling order from left to right. The share of Kommuninvest debt is higher when decomposed on a municipal group-level where 42 municipal groups exclusively rely on Kommuninvest funding. In addition to these, 171 municipalities have Kommuninvest debt shares exceeding $70 \%$ of their total debt and 35 additional municipalities have shares greater than $50 \%$.

The lower total debt share of $48.3 \%$ is due to that a few large actors such as municipalities in the Stockholm region are not Kommuninvest members as of yet. Nevertheless, Fig. 2 suggests that the data are more representative of the sector as a whole than one would initially suspect. This gives support for the generalizability of the results presented in this paper.

\subsection{Intertemporal diversification measures}

In order to describe the maturity structure of the debt portfolios five measures are constructed. I propose the following measures which are primarily constructed to capture the different distributional characteristics of the maturity structure.

Weighted Standard Deviation of Time to Maturity ${ }^{4}$ :

\footnotetext{
4 It is to be noted that the weighted standard deviation does not perfectly capture the characteristics of intertemporal diversification as defined in previous sections. For instance, assume a portfolio that contains 2 loans, with equal principal and 1 and 5 years of time to maturity respectively. Adding an additional loan to the portfolio with a time to maturity greater than 1 and less than 5 years may very well decrease the value of the measure. Given the observed portfolios (see Sect. 4.2 below) of Swedish municipalities it is nevertheless argued that, on average, an increase in the measure corresponds to an increase in diversification since the portfolios are characterized by relatively short maturity structures.
} 


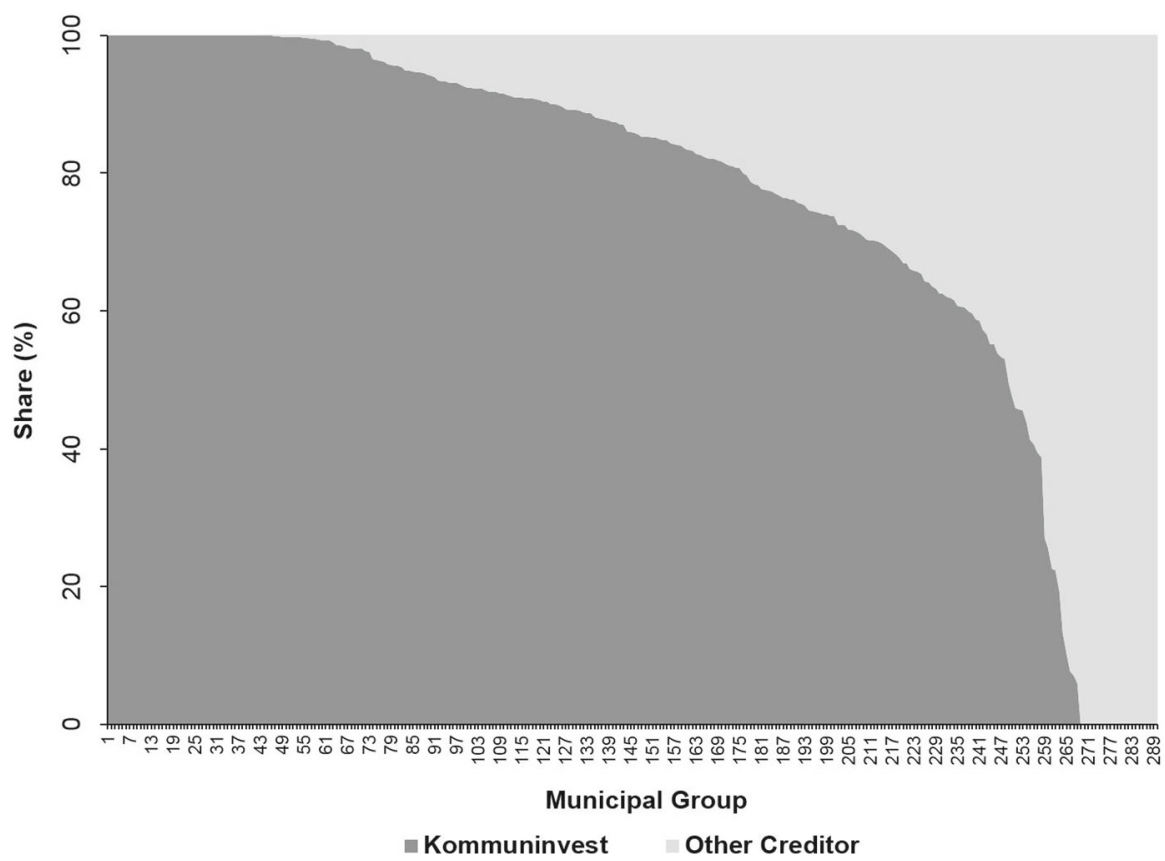

Fig. 2 Kommuninvest share of debt per municipal group for year 2015

$$
\begin{gathered}
\sigma_{i, t}=\sqrt{\frac{N_{i, t}}{N_{i, t}-1} \frac{\sum_{j=1}^{N} w_{i, t, j}\left(M_{i, t, j}-\bar{M}_{i, t}^{w}\right)^{2}}{\sum_{j=1}^{N} w_{i, t, j}}} \\
\text { where } \bar{M}_{i, t}^{w}=\frac{\sum_{j=1}^{N} w_{i, t, j} M_{i, t, j}}{\sum_{j=1}^{N} w_{i, t, j}} \\
w_{i, t, j}=\frac{P_{i, t, j}}{\sum_{j=1}^{N} P_{i, t, j}}
\end{gathered}
$$

Equation 1 is the weighted standard deviation of the time to maturity at the point in time $t$, for municipality $i$ where the sum of weights $\sum_{j=1}^{n} w_{i, t, j}$ is equal to 1 . $M_{i, t, j}$ is the time to maturity of an active loan $j, \bar{M}_{i, t}^{w}$ is the weighted mean time to maturity for all active loans in the portfolio, and $N_{i, t}$ is the number of active loans. Equation 3 represents the contract-specific weights where $P_{i, t, j}$ is the loanspecific principal amount. The undiscounted principal amount is used in the dispersion calculations following the work of Choi et al. (2018).

Interquartile Range of Time to Maturity (IQ Range) is:

$$
\begin{aligned}
\mathrm{IQR}_{i, t} & =Q_{3}\left\{M_{i, t, 1}, \ldots, M_{i, t, n}\right\}-Q_{1}\left\{M_{i, t, 1}, \ldots, M_{i, t, n}\right\} \\
& =p_{75}\left\{M_{i, t, 1}, \ldots, M_{i, t, n}\right\}-p_{25}\left\{M_{i, t, 1}, \ldots, M_{i, t, n}\right\}
\end{aligned}
$$


The dispersion measure as shown by Eq. 4 is the difference between the time to maturity of the 3rd and 1st quartiles, or equivalently the difference between the 75 th and 25th percentiles. By construction this measure does not incorporate the $25 \%$ highest and lowest observations in the data and therefore does not include outliers.

Weighted Mean Interquartile Range of Time to Maturity (WMIQR (i), (ii)) is:

$$
\begin{gathered}
\mathrm{WMIQR}_{i, t}=\sum_{M \in \mathrm{A}} w_{i, t}^{1} M_{i, t}-\sum_{M \in \mathrm{B}} w_{i, t}^{2} M_{i, t} \\
\text { where } \mathrm{A}=\left\{M_{i, t, u}, P_{i, t, u} \mid M_{i, t, u} \geq Q_{x}\left\{M_{i, t, 1}, \ldots, M_{i, t, n}\right\}\right\} \\
\mathrm{B}=\left\{M_{i, t, l}, P_{i, t, l} \mid M_{i, t, l} \leq Q_{y}\left\{M_{i, t, 1}, \ldots, M_{i, t, n}\right\}\right\} \\
w_{i, t, u}^{1}=\frac{P_{i, t, u}}{\sum_{P \in \mathrm{A}} P_{i, t}} \\
w_{i, t, l}^{2}=\frac{P_{i, t, l}}{\sum_{P \in \mathrm{B}} P_{i, t, i}}
\end{gathered}
$$

In order to take into account the size of each loan when calculating the range the above measure is constructed. Equation 5 represents the range between two weighted means. Equations 6 and 7 define two sets: A and B. Both are comprised of $M$ and $P$ pairs for municipal group $i$, at time $t$. Set $\mathrm{A}$ is conditioned upon that $M$ is greater than or equal to quartile, $Q_{x}$. Set B is conditioned upon that $M$ is less than or equal to quartile, $Q_{y}$. Weights are calculated over both sets by the principal values as shown by 8 and 9 . Two measures are constructed using this method where $Q_{x}$ and $Q_{y}$ differ. First, $Q_{x}$ represents the 3rd quartile, or the 75th percentile, and $Q_{y}$ the 1st quartile, or the 25 th percentile. Thus, by construction this measure only incorporates the $25 \%$ highest and lowest observations in the range calculation. Hereafter, this measure will be denoted the WMIQR (i). Second, $Q_{x}=Q_{y}=Q_{2}$ where $Q_{2}$ is the 2nd quartile, or the median. In contrast, this calculation incorporates all loans. This measure will be denoted WMIQR (ii).

In addition to the abovementioned intertemporal dispersion measures one supplementary measure is constructed to capture another distributional characteristics of the maturity structures.

Weighted Mean of Time to Maturity is:

$$
\mu_{i, t}=\frac{\sum_{j=1}^{N} w_{i, t, j} M_{i, t, j}}{\sum_{j=1}^{N} w_{i, t, j}}
$$

$\mu$ is the weighted mean of time to maturity of the municipal portfolio $i$, at time $t$. The sum of weights $\sum_{j=1}^{n} w_{i, t, j}$ is equal to 1 . The weighted mean is interpreted as a frequency variable which shows how often the debt is refinanced. 


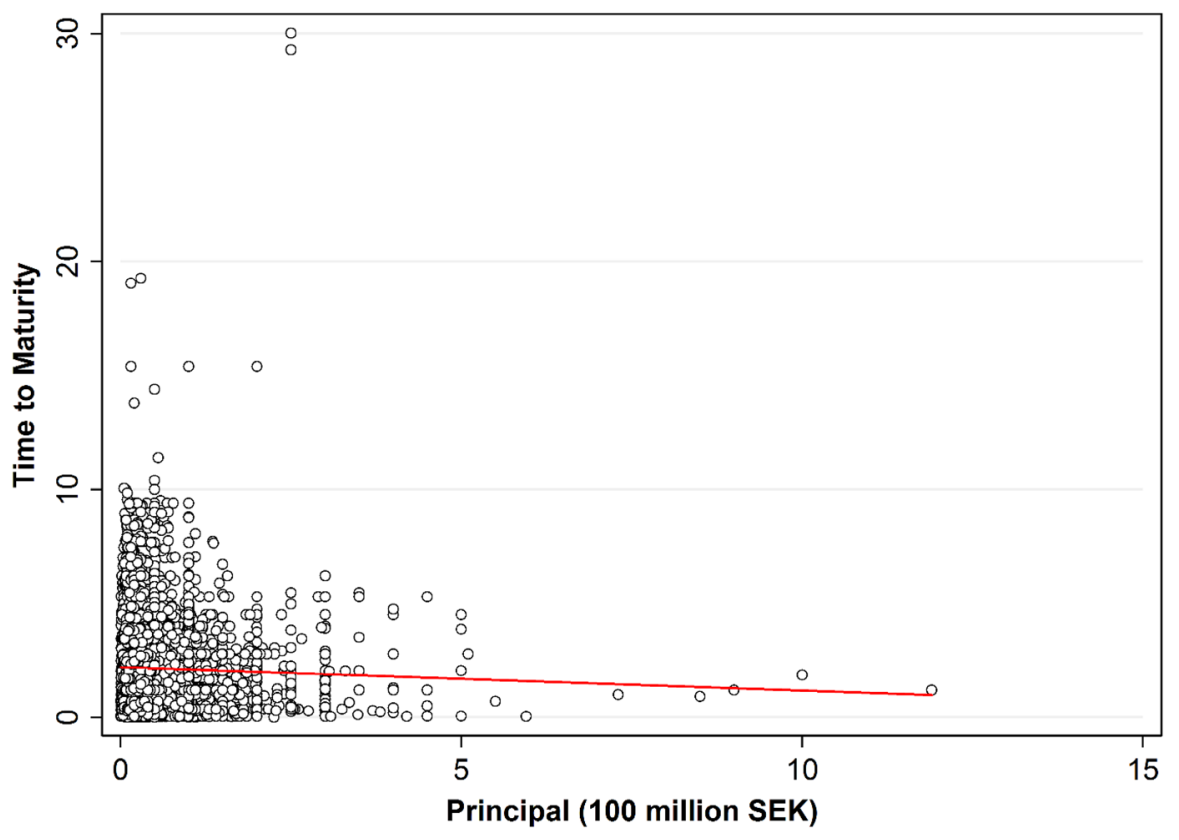

Fig. 3 Relation of the maturity structure and the principal amount as of June 2016

\subsection{Summary statistics and the evolution of the measures}

Table 4 in "Appendix" gives a summary of the time to maturity variable and the abovementioned measures. The average time which a municipal group is represented in the data is shown by $\overline{\mathrm{T}}$ and is approximately 153 months or 13 years. As previously discussed the portfolios of the municipal groups are characterized by a short maturity structure. The average time to maturity is overall 2.201 years and the average weighted mean is 2.210 , suggesting that time to maturity and principal amount are positively correlated. This is due to the fact that the latter is weighted by the principal amounts and the former is not. However, when graphing the principal amount against the time to maturity for all loans as of June 1, 2016, the relationship is negative as shown in Fig. 3. Notice that the average values of Table 4 are calculated over the whole time series for all municipal groups while Fig. 3 is depicted at a certain point in time $t$. The intertemporal diversification as expressed by the standard deviation is 1.779 years. The short maturity structure in addition to a relatively low degree of intertemporal diversification suggests that large debt volumes are rolled over with a high frequency.

Per construction the IQ range is lower than the WMIQR (i); they take on the values, 2.324 and 3.571 years, respectively. The magnitude of the WMIQR (ii) depends on the dispersion of the maturity structure for all loans and their relative size. Since the WMIQR (ii) measure has a lower value compared to the IQ range, 2.253 and 2.324 years, respectively, it suggests that the principal amounts of loans closer to the median are larger in magnitude. However, this difference is relatively small. Moving "down" from the WMIQR (i) to the IQ range the dispersion falls with approximately 1.25 years. 


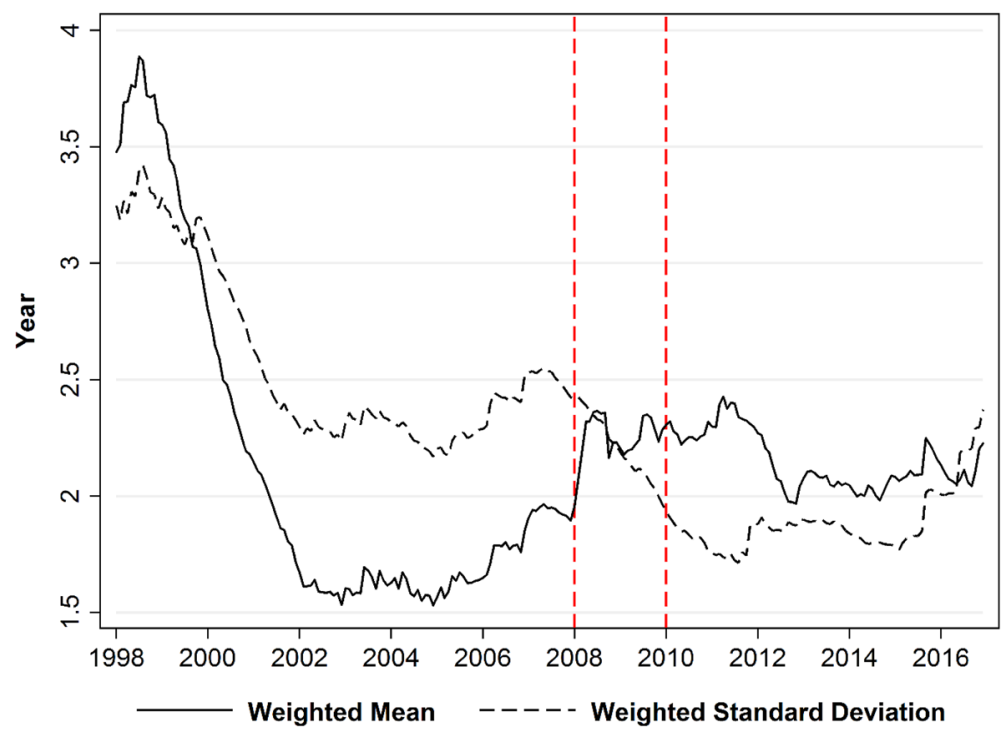

Fig. 4 Evolution of the moment measures, January 1998 to June 2016

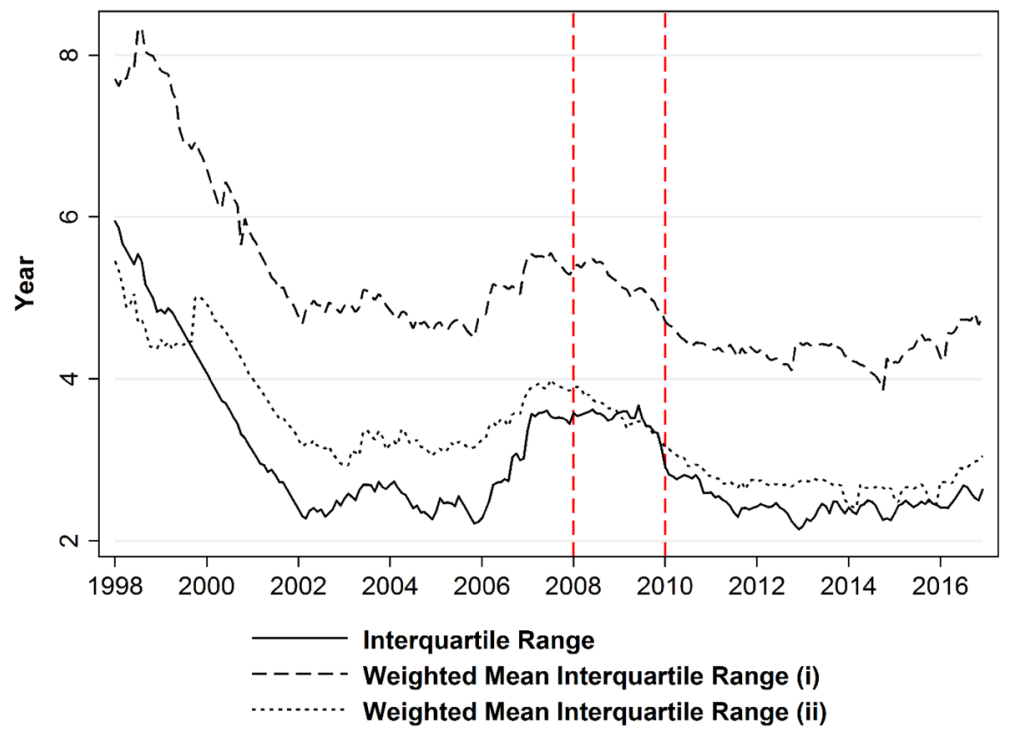

Fig. 5 Evolution of the range measures, January 1998 to June 2016. All measures are calculated on a monthly basis for the whole municipal sector

Figures 4 and 5 depict the evolution of the measures over the 19-year period for the total sector debt portfolio, i.e., the measures are only calculated over $t$ and $i$ is omitted. These series are not used for the main analysis and should not be directly compared to the regression results. The figures are only intended to give a general overview of the evolution of the measures on a sector level. 
All measures have negative trajectories for the initial 5 years after which they stabilize with some minor fluctuations. The period of the 2008-2009 financial crisis is illustrated by the two vertical lines. The weighted mean had a positive trajectory prior to the crisis which continued through the crisis period following a fall for the post-crisis period. The weighted standard deviation had a positive trajectory for the pre-crisis period and then started to fall prior to the crisis and continued its negative trajectory for the subsequent periods.

Figure 5 depicts the evolution of the three range measures over the same time period. The series for the three range measures are very similar. Dispersion started to greatly increase around the start of 2006 and continued its trajectory up to early 2008. During the crisis dispersion started to fall and continued to fall for the post-crisis period to once again stabilize around its 2002-2005 levels at the start of 2011.

\section{Methodology}

In this section the main models are presented followed by an overview of the explanatory variables and their relationship to prior research. The fixed-effects multiple regression model is estimated for municipality $i=1, \ldots, N$ which are observed for multiple time periods $t=1, \ldots, T$.

$$
y_{i, t}=v_{i}+m_{t}^{\prime} \beta_{1}+x_{i, t}^{\prime} \beta_{2}+z_{t}^{\prime} \beta_{3}+u_{i, t}
$$

In Eq. 11 the abovementioned measures act as dependent variables, $y_{i, t}$. The vector $m_{t}^{\prime}$ is a 2-dimensional row vector of time-variant crisis variables. These are the variables of interest and $\beta_{1}$ is by extension a 2-dimensional column vector of the estimated parameters that measure the effects of the financial crisis. The vector $x_{i, t}^{\prime}$ is a 3 dimensional row vector of panel data fiscal control variables. The 6-dimensional vector $z_{t}$ is a collection of interest rate and other time-variant controls. The parameter $v_{i}$ is the municipal fixed effects, and $u_{i, t}$ is the idiosyncratic error terms. It is common practice to include time-fixed effects when dealing with panel data but as can be seen by Eq. 11, these are excluded from this analysis. In this paper the focus is instead to disentangle the time-varying effects using a wide range of macroeconomic time series identification variables. One can make the argument that the most important timevarying factor impacting the municipal choice of term is the term structure of interest rates which is controlled for in the model. Thus, the chosen explanatory variables are expected to sufficiently capture the macroeconomic variations without the need of including time-fixed effects. ${ }^{5}$

\footnotetext{
${ }^{5}$ Controlling for time-fixed effects while omitting $m_{t}$ and $z_{t}$ yields very similar results as those of the main model, suggesting that the main model as shown by Eq. 11 is well specified. These results from the time-fixed effects model are not included in the paper but are available from the author upon request.
} 


\subsection{Explanatory variables}

\subsubsection{Crisis variables}

Two dummy variables are generated that control for the peri- and post-financial crisis. The financial crisis variable takes the value 1 for the years 2008 and 2009 and the post-financial crises variable takes the value 1 for all subsequent years. The years 2008 and 2009 seem like the appropriate period so as to characterize the financial crisis, although some of its effects did spill over to the pre- and post-periods. In July 2007 the Swedish stock market started to fall which it continued to do up until October 2008 at which point the OMXS30 index had declined by approximately 58\%. Following the Lehman crash in September 2008 it was revealed that several of the Swedish banks owned Lehman issued derivatives. The Riksbank started lowering the policy rate in September of 2008 from $4.75 \%$ to 0.25 in July 2009. The effects of the financial crisis are difficult to predict. The liquidity problems met by the municipal sector during the crisis could be interpreted by the sector as a signal that emphasized the need for intertemporal diversification. One could, on the other hand, make the argument that since Kommuninvest acted as a safe haven during the crisis, they have proven competent in supplying the sector with financing even during turbulent times. This could be interpreted by the sector as intertemporal diversification being unnecessary.

\subsubsection{Fiscal control variables}

Taking inspiration from Missale and Blanchard (1994) a measure is constructed that mimics the debt-to-GNP ratios suggested. The total outstanding debt for each municipality and month is calculated from the main data set received from Kommuninvest. Using gross regional product would be ideal; however, these data have not officially been reported for a sufficiently long period of time and therefore the annual tax base for each municipality is used as a proxy. The annual tax base (100 million SEK) is collected from Statistics Sweden (2017) for the period 1998-2016. ${ }^{6}$ If this relationship is proven to be statistically significant for sub-sovereign data, we can conclude that there are additional dimensions that are not accounted for by the authors since it is unlikely that the monetary policies of the central government are internalized by the local governments.

Uncertainty regarding the tax base is of importance when choosing maturity structure since the government has to account for the uncertainty to successfully hedge against low-productivity states of nature and thus smooth tax rates over different states (Barro 1995, 1997). The tax base is detrended by annual log-differences, and the municipal-specific tax base standard deviation is calculated for year $t$ over a 5-year time interval, $\left\{T B_{t-1}, T B_{t-2}, \ldots, T B_{t-5}\right\}^{7}$ The volatility of the tax base is expected to be positively correlated with the intertemporal diversification measures. Municipalities with a volatile tax base may want to avoid a large share of the outstanding debt

\footnotetext{
6 The tax base has an annual time frequency and is held constant intra-year while the total debt has a monthly time frequency.

7 The tax base standard deviation has an annual time frequency and is held constant intra-year.
} 
to mature within a short time interval due to the risk of illiquidity and the uncertainty of tax revenues.

Cestau (2010) finds a convex relationship between the short-term debt share of nation states and their per capita income levels. The arguments presented by Cestau regarding the financing behavior are not specifically restricted to central governments and would be expected to hold for true for sub-sovereign governments as well. Since Swedish municipalities as a group have relatively high and homogenous income levels, largely due to fiscal equalization, it is expected that per capita income will have a negative effect on the average time to maturity. Thus, in this paper the focus will be on the upper part of the per capita income distribution. Cestau does not touch upon the dispersion of the maturity structure. There seems to be a relatively high degree of correlation between the intertemporal dispersion measures and the mean time to maturity as suggested from the figures in previous section. Therefore, it is expected that the per capita income measures will be similarly related to these as well. The annual per capita incomes (thousand SEK) are collected from Statistics Sweden (2017) for all municipalities. ${ }^{8}$

\subsubsection{Financial ratios}

Three financial ratios are added so as to control for the financial health of the municipality which in turn could affect the choice of debt undertaken. The first measure is the operating cash flow (OCF) ratio which indicates of how well the municipality can live up to its liabilities in the short term. The ratio is calculated as current assets, excluding inventory and development land assets, as a share of current liabilities. The second measure is the equity-to-asset (EA) ratio which is calculated as the equity share of total assets while excluding pension liabilities pertained to the pre-1998 period. This measure can be interpreted as the long-term ability of the municipality to live up to its liabilities. The third and final ratio is the annual accumulated surplus as a share of the sum of annual tax revenues and state and municipal equalization grants (ST). The ratios are published by Statistics Sweden and collected from the Kolada (2018) database. ${ }^{9}$

The OCF and the ST ratios can be interpreted as the financial slack of the municipality which would be expected to be negatively correlated with the average time to maturity since it would give the municipalities more leeway to undertake a higher degree of short-term debt. The EA ratio is inversely related to the financial leverage of the municipality, and therefore, by the same arguments laid out by Missale and Blanchard (1994) it is expected that the ratio is positively correlated with the average time to maturity. However, the EA and ST ratios are also measures of wealth and are assumed to be positively correlated with the per capita income of the municipal population. Therefore, following the arguments of Cestau (2010), one would expect the EA and ST ratios to be negatively correlated with the average time to maturity. In summary, it is difficult to predict the effects of the ratios since both positive and negative effects can be argued.

\footnotetext{
8 The per capita income has an annual time frequency and is held constant intra-year.

9 All three financial ratios are of an annual frequency and are held constant intra-year.
} 


\subsubsection{Interest rate control variables}

Interest rates are typically monotonically increasing in the term. Therefore, intertemporal diversification is a costly endeavor which requires long-term debt. How large this additional cost is depends on the term structure of interest rates. As shown by Litterman and Scheinkman (1991) there are three factors that account for over $96 \%$ of the variation of the term structure: the level, slope and curvature. Below three variables are constructed so as to capture the variability in the term structure which in turn affects the choice of maturity structure.

In general the shortest borrowing rate available to the municipal sector is the 3month STIBOR rate and this will act as a proxy for the intercept of the interest rate curve. Since interest rates are usually monotonically increasing, the 3-month STIBOR spot rate acts as a level variable which indicates how high or low interest rates are for the whole term structure. The 3-month STIBOR spot rate is expected to be negatively related to the dispersion measures and the mean since when the cost of borrowing increases there will be an effort to reduce costs. This will result in a higher degree of short-term financing and thus a lower degree of intertemporal diversification.

The slope and curvature are calculated for each month in the data. The monthly average 3-month STIBOR spot rate and the 2-, 5-, 7- and 10-year government bond rates are gathered from the Sveriges Riksbank homepage (2017a, b). The slope and curvature are estimated by a second-degree polynomial estimated in the neighborhood of the average term.

$$
r_{t, i}=\gamma_{t}+\delta_{1, t}\left(T_{t, i}-\bar{T}\right)+\delta_{2, t}\left(T_{t, i}-\bar{T}\right)^{2}+\eta_{t, i}
$$

In Eq. $12 r_{t, i}$ and $T_{t, i}$ are the interest rate and term pair $i$ at time $t$ and $\bar{T}=$ $\frac{2+5+7+10}{4}=6$ is the average term which is constant for all periods. The slope parameter $\delta_{1, t}$ acts as the slope variable in the main model and $\delta_{2, t}$ as the curvature. The functional form of Eq. 12 allows for the joint estimation and interpretation of the slope and the curvature parameters while minimizing the correlation between the two. This reduces the multicollinearity problem in the main model.

The slope is expected to be negatively related to the intertemporal dispersion measures and the weighted mean. An increase in the slope, ceteris paribus, implies that the average marginal cost of a loan with an infinitesimal short term increases. ${ }^{10}$ Thus, an increase in the slope implies that a long-term loan becomes more expensive relative to a short-term loan. $\delta_{2, t}>0$ implies that Eq. 12 is convex, and for values of $\delta_{2, t}<0$ it is concave. Convexity implies that the slope and the marginal cost are low for short-term loans, but high for long-term loans. By the same argument as for the slope parameter, a steep (flat) slope would induce the municipalities to choose a shorter (longer)-term loan due to an increase (decrease) in marginal cost. In the case of a convex term structure we would expect to have a pooling in the middle and that dispersion will

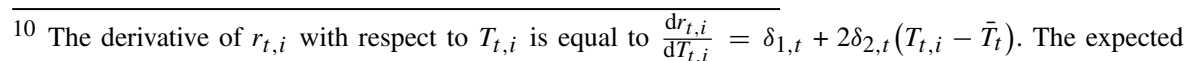
value of the expression becomes $E_{t}\left[\frac{\mathrm{d} r_{t, i}}{\mathrm{~d} T_{t, i}}\right]=\delta_{1, t}+2 \delta_{2, t}\left(E_{t}\left[T_{t, i}\right]-\bar{T}_{t}\right)$ where $E_{t}\left[T_{t, i}\right]=\bar{T}_{t}$. Thus, $E_{t}\left[\frac{\mathrm{d} r_{t, i}}{\mathrm{~d} T_{t, i}}\right]=\delta_{1, t}=$ average marginal cost at $t$. 
be negatively correlated with $\delta_{2, t}$. In contrast, a concave term structure will result in a separation where in general borrowers will be pushed to the extremes of the term structure resulting in an increase in dispersion. In terms of the weighted mean measure the effects could be either positive or negative depending on the ex-ante size of the mean and where the largest difference in slope occurs in the term structure.

In addition to these measures a dummy variable that controls for negative interest rates is generated. The variable takes the value 1 when 3-month STIBOR rate takes a value below zero, that is, since April 2015. The variable is expected to be negatively related to the intertemporal dispersion measures and the average time to maturity. This is due to the fact that the term structure typically is monotonically increasing and therefore short-term rates will be the first to cross the zero interest rate threshold when interest rates fall. If the mean maturity of an observed portfolio is greater than the zero interest rate term, then it is expected that the municipalities will to a higher extent borrow at negative interest and thus choose a shorter maturity structure. The contrary may be true if the maximum term associated with negative rates exceeds the municipalities mean maturity structure.

\subsubsection{Financial market liquidity}

Market liquidity is a multifaceted phenomenon which is difficult to control for. Liquidity can be decomposed into multiple different characteristics such as tightness, immediacy, depth, breadth and resilience (Sarr and Lybek 2002). In this paper the monthly turnover of government bonds as a share of total outstanding government debt is use as a measure of market liquidity. ${ }^{11}$ The monthly outstanding government debt is collected from the Swedish National Debt Office (2018), and the monthly turnover is published by Sveriges Riksbank and collected from Macrobond for the years 1998-2016. On the one hand, high liquidity can be negatively correlated with intertemporal diversification and the average time to maturity since the risk of illiquidity will be lower and credit will be abundant. On the other hand, high liquidity will reduce bond premiums, which in turn will push down interest rates. Since short-term bonds are more liquid than long-term bonds, it is expected that the latter will be more sensitive to changes in liquidity. Therefore, when liquidity increases, there will be a flattening of the yield curve which, as argued previously, would be positively correlated with dispersion and the average time to maturity. However, since interest rates are also controlled for in the model, following the former argument, it is expected that liquidity will be negatively correlated with dispersion and the mean time to maturity.

\subsubsection{Election control variable}

So as to investigate the recurring effects of the election cycle as expressed by Nordhaus (1975) a variable is constructed to control for the number of years up until the next parliamentary elections. Swedish governments serve a 4-year term in office; thus, the

\footnotetext{
11 These types of volume-based measures are most useful when measuring market breadth and take on high values when the market is characterized by numerous and large orders with a minimal impact on prices. In addition, volume-based measures are also correlated with market depth since deep markets tend to foster breadth where large orders can be divided into several smaller ones.
} 
variable takes the value 1 for each election year and then resets to 4 the subsequent year and counts down to the next election. As stated in previous sections, from a theoretical point of view it is expected that the measures will be negatively correlated with the election variable, indicating that more long-term debt is undertaken when close to an election. However, if the opposite is true, a possible explanation may be the deterring effect of the legislation.

In the next section the results from the main model are presented followed by robustness tests.

\section{Results}

In this section the main results are presented for the model outlined in the previous sections. The estimates from the fixed-effects models are presented in Table 3.

The crisis variable has a positive effect on all variables. As discussed in previous sections, on the aggregate there is an increase in the measures prior to and during the crisis period. During the crisis the mean increased by approximately 1.16 years, or on average approximately 212 days for each of the 2 years. The dispersion measures increased by $0.12-0.72$ years, or 44-263 days depending on the measure. For the post-crisis period there is a negative impact on all the measures in relation to the crisis period. However, the post-crisis WMIQR (i), WMIQR (ii) and standard deviation are even lower than their corresponding pre-crisis levels. The interquartile range and mean also drop during the post-crisis period but remain on a higher level relative to their pre-crisis levels. Table 5 in "Appendix" shows the results of three fixed-effects models where the log of total portfolio debt, number of loans and the log average loan size are dependent variables. During the crisis the total portfolio debt dropped on average by $20 \%$ and then increased by $5 \%$ for the post-crisis period but remained approximately $14 \%$ lower than its corresponding pre-crisis level. Similarly, the number of loans in the portfolios dropped on average by 2.8 loans and increased slightly for the pre-crisis period. Notice that this does not imply that no new loans are issued during this period; it simply implies that a lower share of the debt is refinanced. However, the average loan size increased during and after the crisis.

The results of Table 3 are consistent with the financial crisis acting as a "wake-up call" for the municipalities. Although, the positive effects were short lived and not sustained for the post-crisis period. The inability to borrow from the banking sector, which historically has proven reliable, highlighted the dangers of illiquidity when the dependence on refinancing is high. Kommuninvest proved its ability to fund the municipal sector during turbulent times. ${ }^{12}$ This seems to have been interpreted by the sector as intertemporal diversification being unnecessary, as indicated by the results for the post-crisis period.

The results in Table 3 indicate that the logarithm of the debt-to-tax base ratio suggested by Missale and Blanchard is statistically significant for all six measures. A

\footnotetext{
12 It may be argued that the municipalities actually acted optimally since the effects of the crisis were avoided by the aid of Kommuninvest. However, for this to hold it would require that the municipalities had the foresight to determine the level of resilience of Kommuninvest and foresee that Kommuninvest would be able to manage the effects of the crisis.
} 
Table 3 Maturity structure measures, fixed effects, January 1998 to June 2016

\begin{tabular}{|c|c|c|c|c|c|}
\hline & IQ range & WMIQR (i) & WMIQR (ii) & $\mathrm{SD}$ & Mean \\
\hline \multicolumn{6}{|l|}{ Crisis } \\
\hline Crisis & $\begin{array}{l}0.717 * * * \\
(0.04)\end{array}$ & $\begin{array}{l}0.434 * * * \\
(0.04)\end{array}$ & $\begin{array}{l}0.428 * * * \\
(0.03)\end{array}$ & $\begin{array}{l}0.117 * * * \\
(0.02)\end{array}$ & $\begin{array}{l}1.156^{* * * *} \\
(0.03)\end{array}$ \\
\hline Post-crisis & $\begin{array}{l}0.094 * \\
(0.04)\end{array}$ & $\begin{array}{l}-0.334 * * * \\
(0.05)\end{array}$ & $\begin{array}{l}-0.157 * * * \\
(0.04)\end{array}$ & $\begin{array}{l}-0.264 * * * \\
(0.02)\end{array}$ & $\begin{array}{l}1.145^{* * * *} \\
(0.03)\end{array}$ \\
\hline \multicolumn{6}{|c|}{ Financial ratios and fiscal } \\
\hline $\begin{array}{l}\text { Log debt-tax } \\
\text { base ratio }\end{array}$ & $\begin{array}{l}0.087 \text { *** } \\
(0.01)\end{array}$ & $\begin{array}{l}0.187 * * * \\
(0.01)\end{array}$ & $\begin{array}{l}0.103^{* * * *} \\
(0.01)\end{array}$ & $\begin{array}{l}0.024 * * * \\
(0.00)\end{array}$ & $\begin{array}{l}-0.057 * * * \\
(0.01)\end{array}$ \\
\hline $\begin{array}{l}\text { Log tax base } \\
\text { standard } \\
\text { deviation }\end{array}$ & $\begin{array}{l}0.148 * * * \\
(0.02)\end{array}$ & $\begin{array}{l}0.238 * * * \\
(0.02)\end{array}$ & $\begin{array}{l}0.087 * * * \\
(0.02)\end{array}$ & $\begin{array}{l}0.093 * * * \\
(0.01)\end{array}$ & $\begin{array}{l}-0.028 * * * \\
(0.01)\end{array}$ \\
\hline $\begin{array}{l}\text { Log per capita } \\
\text { income }\end{array}$ & $\begin{array}{l}-6.346^{* * * *} \\
(0.44)\end{array}$ & $\begin{array}{l}-5.055^{* * *} \\
(0.51)\end{array}$ & $\begin{array}{l}-5.397 * * * \\
(0.37)\end{array}$ & $\begin{array}{l}-6.372 * * * \\
(0.25)\end{array}$ & $\begin{array}{l}-12.043 \text { *** } \\
(0.31)\end{array}$ \\
\hline $\begin{array}{l}\text { Operating cash } \\
\text { flow ratio }\end{array}$ & $\begin{array}{l}0.001 \text { *** } \\
(0.00)\end{array}$ & $\begin{array}{l}0.002 * * * \\
(0.00)\end{array}$ & $\begin{array}{l}0.001 * * * \\
(0.00)\end{array}$ & $\begin{array}{l}0.000 \\
(0.00)\end{array}$ & $\begin{array}{l}-0.001 * * * \\
(0.00)\end{array}$ \\
\hline $\begin{array}{l}\text { Equity-to-asset } \\
\text { ratio }\end{array}$ & $\begin{array}{l}-0.011 * * * \\
(0.00)\end{array}$ & $\begin{array}{l}-0.023 * * * \\
(0.00)\end{array}$ & $\begin{array}{l}-0.013 * * * \\
(0.00)\end{array}$ & $\begin{array}{l}-0.006^{* * * *} \\
(0.00)\end{array}$ & $\begin{array}{l}-0.004 * * * \\
(0.00)\end{array}$ \\
\hline $\begin{array}{l}\text { Surplus-to-tax } \\
\text { revenue ratio }\end{array}$ & $\begin{array}{l}-0.010^{* * * *} \\
(0.00)\end{array}$ & $\begin{array}{l}-0.011 * * * \\
(0.00)\end{array}$ & $\begin{array}{l}-0.007 * * * \\
(0.00)\end{array}$ & $\begin{array}{l}-0.005^{* * *} \\
(0.00)\end{array}$ & $\begin{array}{l}-0.006^{* * * *} \\
(0.00)\end{array}$ \\
\hline \multicolumn{6}{|c|}{ Financial market } \\
\hline $\begin{array}{l}\text { 3-month } \\
\text { STIBOR }\end{array}$ & $\begin{array}{l}-0.097 * * * \\
(0.02)\end{array}$ & $\begin{array}{l}-0.128 * * * \\
(0.02)\end{array}$ & $\begin{array}{l}-0.068 * * * \\
(0.01)\end{array}$ & $\begin{array}{l}-0.044 * * * \\
(0.01)\end{array}$ & $\begin{array}{l}-0.065^{* * *} \\
(0.01)\end{array}$ \\
\hline Slope & $\begin{array}{l}-3.991 * * * \\
(0.23)\end{array}$ & $\begin{array}{l}-4.867 * * * \\
(0.27)\end{array}$ & $\begin{array}{l}-3.046^{* * * *} \\
(0.20)\end{array}$ & $\begin{array}{l}-1.859 * * * \\
(0.13)\end{array}$ & $\begin{array}{l}-1.901 * * * \\
(0.16)\end{array}$ \\
\hline Curvature & $\begin{array}{l}-18.261 * * * \\
(0.92)\end{array}$ & $\begin{array}{l}-22.873 * * * \\
(1.08)\end{array}$ & $\begin{array}{l}-14.094 * * * \\
(0.79)\end{array}$ & $\begin{array}{l}-7.463 * * * \\
(0.53)\end{array}$ & $\begin{array}{l}-7.738 * * * \\
(0.65)\end{array}$ \\
\hline $\begin{array}{l}\text { Negative } \\
\text { 3-month } \\
\text { STIBOR }\end{array}$ & $\begin{array}{l}0.301 * * * \\
(0.03)\end{array}$ & $\begin{array}{l}0.404 * * * \\
(0.04)\end{array}$ & $\begin{array}{l}0.273 * * * \\
(0.03)\end{array}$ & $\begin{array}{l}0.246^{* * *} \\
(0.02)\end{array}$ & $\begin{array}{l}0.263 * * * \\
(0.02)\end{array}$ \\
\hline $\begin{array}{l}\text { Market } \\
\text { liquidity }\end{array}$ & $\begin{array}{l}-0.435 * * * \\
(0.07)\end{array}$ & $\begin{array}{l}-0.643 * * * \\
(0.08)\end{array}$ & $\begin{array}{l}-0.224 * * * \\
(0.06)\end{array}$ & $\begin{array}{l}0.001 \\
(0.04)\end{array}$ & $\begin{array}{l}0.641 * * * \\
(0.05)\end{array}$ \\
\hline \multicolumn{6}{|l|}{ Other } \\
\hline Election & $\begin{array}{l}0.016^{*} \\
(0.01)\end{array}$ & $\begin{array}{l}0.026^{* * *} \\
(0.01)\end{array}$ & $\begin{array}{l}0.009 \\
(0.01)\end{array}$ & $\begin{array}{l}0.002 \\
(0.00)\end{array}$ & $\begin{array}{l}0.045^{* * * *} \\
(0.00)\end{array}$ \\
\hline Year trend & $\begin{array}{l}0.107 * * * \\
(0.02)\end{array}$ & $\begin{array}{l}0.107 * * * \\
(0.02)\end{array}$ & $\begin{array}{l}0.137 * * * \\
(0.01)\end{array}$ & $\begin{array}{l}0.136^{* * * *} \\
(0.01)\end{array}$ & $\begin{array}{l}0.201 * * * \\
(0.01)\end{array}$ \\
\hline Constant & $\begin{array}{l}35.744 * * * \\
(2.11)\end{array}$ & $\begin{array}{l}31.159 * * * \\
(2.48)\end{array}$ & $\begin{array}{l}30.084 * * * \\
(1.80)\end{array}$ & $\begin{array}{l}34.393 * * * \\
(1.22)\end{array}$ & $\begin{array}{l}62.719 * * * \\
(1.48)\end{array}$ \\
\hline$N$ & 41,349 & 41,349 & 41,349 & 39,944 & 41,349 \\
\hline$R^{2}$ (within) & 0.043 & 0.045 & 0.035 & 0.106 & 0.162 \\
\hline$\sigma_{u}$ & 1.066 & 1.408 & 1.019 & 0.861 & 1.371 \\
\hline$\sigma_{e}$ & 1.449 & 1.705 & 1.239 & 0.797 & 1.021 \\
\hline$\rho$ & 0.351 & 0.406 & 0.403 & 0.539 & 0.643 \\
\hline
\end{tabular}

Standard errors in parentheses

$* p<0.05, * * p<0.01, * * * p<0.001$ 
$1 \%$ increase in the ratio results in a decrease in the weighted mean time to maturity by approximately 21 days. This result is expected and in line with what was shown by Missale and Blanchard. Municipalities with higher debt-to-tax base ratio in general prefer short-term debt to a higher extent. Interestingly, the results show that the ratio is positively correlated with all intertemporal dispersion measures, implying that high leverage municipalities tend to choose a more disperse maturity structure. These results emphasize the importance of investigating different distributional aspects of the maturity structure.

Even though it is true that high leverage governments on average prefer short-term debt, the results show that the risks of short-term financing are internalized by the municipalities and reduced by higher dispersion. Being able to reproduce the results presented by Missale and Blanchard suggests that the monetary policy argument is only part of the story. High leverage municipalities may be financially constrained to a higher extent and therefore in an attempt to reduce the cost of borrowing prefer short-term debt.

The logarithm of the tax base standard deviation is negatively correlated with the mean and positively correlated with the intertemporal dispersion measures. This suggests that when a municipality faces uncertainty regarding future tax revenues, it will choose a more dispersed debt maturity structure. A $1 \%$ increase in the tax base volatility results in a decrease in the mean by approximately 10 days, which is a relatively small impact. Dispersion increases by 0.08-0.2 years, or 29-73 days, depending on the measure. As suggested by Barro the government would choose an appropriate maturity structure so as to offset any uncertainty in their tax revenues. The results reinforce the arguments presented by Barro. Municipalities that have a volatile tax base choose a more disperse maturity structure so as to reduce the repayment amount at each period.

Per capita income has a substantial impact on the measures. As suggested by Cestau, governments of high-income countries prefer short-term debt since their creditworthiness implies that the risk of illiquidity is small. The results show that this is also the case for Swedish local governments. A $1 \%$ increase in per capita income results in a 12 -year decrease in the mean time to maturity. Notably, per capita income also has a large effect on dispersion which was not considered by Cestau. A $1 \%$ increase in per capita income results in a 5-to-6.4-year decrease of intertemporal dispersion. These effects do seem unreasonably large and can potentially be explained by a few outlier municipalities. This will be further investigated later in this section. The arguments presented by Cestau are also applicable for the effects on dispersion. Diversification and accordingly dispersion can be viewed as an illiquidity insurance that comes at a premium, for high-income municipalities the risk of illiquidity is low and therefore the incentives for diversifying are also low, resulting in a negative relationship between dispersion and per capita income. The OCF ratio has a negative but economically small impact on the mean time to maturity. This is consistent with the fact that municipalities that have a higher degree of financial slack will prefer a higher degree of short-term debt. The OCF ratio is also positively correlated with the dispersion measures. The EA and ST ratios have a slightly larger impact and mimic the estimates of the per capita income variable, suggesting that richer municipalities also have higher EA and ST. 
As expected the 3-month STIBOR rate, slope and curvature variables have a negative effect on dispersion and the mean. The dummy variable controlling for negative rates has a positive effect on dispersion and the mean. The effect of negative interest rates depends on which maturity is associated with zero interest and if this maturity is less or greater than the mean time to maturity of the portfolio. If the mean is above the zero threshold, it would be expected that the effect of negative interest rates would have a negative effect on the mean since the municipalities would like to reap the benefits from the negative interest rates. In this scenario, there is no clear reason why negative rates would have a positive effect on the maturity structure. On the other hand, if the mean is below the threshold, then it is easy to imagine how the relationship could be positive if one assumes that municipalities prefer long-term loans at zero interest to short-term loans at negative interest. The results from the regression suggest that the latter is the case. Both the 3-month STIBOR rate, which controls for the level, and the negative interest rate variable being statistically significant suggest that there is a perceived difference between negative interest rates and a simple downward shift of the term structure in the positive range. It seems that a zero interest rate loan is viewed as being sufficient and beyond this point attention turns to the minimization of risks (i.e., maximizing the term of a zero interest loan). The reason for this behavioral change is most likely due to the municipal sectors acknowledgement of the unconventionality of negative rates and expectation of increasing rates in the future. Finally, market liquidity has a positive effect on the mean time to maturity but a negative effect on dispersion.

The election variable estimates show that dispersion and the mean time to maturity of the portfolios fall when close to an election. This is consistent with local governments refraining from pushing repayments to the next period. One possible explanation could be that such strategic maneuvering is at odds with sound financial management and the prohibition of speculative practices as stated in the Swedish Local Government Act. Also, if the view held by the electorate regarding this type of strategies is overall negative, it could also act as a deterrent.

\subsection{Sensitivity analysis}

In this part of the section robustness testing is conducted for the abovementioned fixed-effects model. First, we will run our regressions using least absolute deviation, thereby controlling for potential outliers. As previously discussed, there have been a large number of municipalities joining Kommuninvest over the years and that new memberships peaked during the financial crisis. In addition, the Kommuninvest market share has steadily been increasing over the years. Second, we will assess whether the inflow of new members or the rebalancing of municipal portfolios is causing the results or whether our findings are indeed driven by changes in municipal financing behavior.

\subsubsection{Least absolute deviation regression}

The benefit of quantile estimation such as a least absolute deviation (LAD)/median regression is that these are more robust when faced with outliers and non-normal errors 
compared to least-square estimation. An appropriate method is the generalized quantile estimator developed by Powell $(2014,2015)$, which then was extended for panel data quantile regressions with fixed effects by the same author in $2016 .{ }^{13}$ Results are presented in Table 6 in "Appendix." Comparing the results of the FE LAD regressions to the main result suggests that the main regression results are robust. Nearly all estimates are statistically significant with the same sign as for the main results. Most notably the annual trend has overall the opposite impact. In addition, per capita income now has a positive effect on the interquartile range instead of a negative as was the case in the main results. The large effects of per capita income presented in Table 3 are now significantly reduced.

\subsubsection{Subsample regression}

Since there was a large inflow of new Kommuninvest member municipalities during the financial crisis, it could be the case that the new members are comparably different to the older ones and that the change in composition of municipalities to some extent is driving the results. To investigate if this is the case, the same regressions as those of Table 3 are estimated for 158 municipalities that joined Kommuninvest prior to January 2006. The estimates are presented in Table 7 in "Appendix." It is shown that the results are consistent with those presented in Table 3 since the estimates are similar in direction and magnitude. This suggests that the results are not driven by the large inflow of new members.

Likewise, the main results could also be affected by municipalities rebalancing their portfolios and moving a larger share of their total debt to Kommuninvest. Thus, the change in the measures could simply be due to this mechanical factor. In an effort to control for this municipalities are categorized by their portfolio composition rate of change during the financial crisis. Total outstanding debt of each municipality as of January 1, 2008, 2009 and 2010, is provided by Kommuninvest gathered from the municipal annual financial statements for the years 2007, 2008 and 2009. Using this in combination with the main data each municipal-specific Kommuninvest debt share is calculated. Municipalities are then categorized by the average annual Kommuninvest share change for the years 2008 and 2009. The main model is then estimated only including municipalities that changed their Kommuninvest share by less than 5 percentage points, 88 municipalities in total. ${ }^{14}$ Table 8 in "Appendix" shows that the results are very similar to those of the main regressions. The most notable difference is that the dispersion measures do fall during the post-crisis period but not as much as to reach their respective pre-crisis levels and that mean time to maturity is highest for the

\footnotetext{
13 This is done by applying the STATA-package qregpd developed by Baker et al. (2016) based on the work of Powell (2016) where standard errors are estimated by a Markov chain Monte Carlo (MCMC) estimation method by the Nelder-Mead algorithm (1965). The algorithm preforms 10000 draws where $7.5 \%$ of these are dropped during the burn-in period for each regression with an acceptance rate is set to 0.234 .

14 The Kommuninvest share is calculated as $S_{i, t}=\frac{D_{i, t}^{K I}}{D_{i . t}^{\text {Tot }}}$ where $D_{i, t}^{K I}$ and $D_{i, t}^{T o t}$ are the Kommuninvest specific and total debt of municipality $i$ at point in time $t$. The average share change is then calculated as $\frac{\Delta S_{i, 2009}+\Delta S_{i, 2008}}{2}=\frac{S_{i, 2009}-S_{i, 2008}+S_{i, 2008}-S_{i, 2007}}{2}=\frac{S_{i, 2009}-S_{i, 2007}}{2}$. Municipalities are included if $\left|\frac{S_{i, 2009}-S_{i, 2007}}{2}\right|<0.05$.
} 
post-crisis period. Thus, we can conclude that the results are not driven by portfolio rebalancing and an increased inflow of loans to Kommuninvest since the estimates remain robust even for municipalities which had a relatively constant portfolio composition during the crisis. As discussed previously, Kommuninvest aims to maintain a relatively uniform margin across the whole term structure and has historically supplied credit at any term without restriction. This further supports the claim that the results are due to changes in municipal behavior rather than driven by mechanical factors, pricing or restrictions on credit.

Finally, we can confirm that the 2008-2009 financial crisis and other macroeconomic factors such as interest rates had a statistically significant effect on the Swedish municipality's choice of maturity structure. Additionally, the results are in line with previous research by Missale and Blanchard (1994), Barro $(1995,1997)$ and Cestau (2010).

\section{Conclusions}

This paper contributes to the existing body of research by bridging the gap between empirical work on the maturity structure of debt done on the sovereign and subsovereign levels of government. This is done by presenting a comprehensive analysis of a unique data set. A financial framework for risk mitigation is discussed which is more suitable and manageable from a sub-sovereign government perspective. In addition, a number of measures are proposed to capture the distributional characteristics of the maturity structure of debt.

The results indicate that the financial crisis was associated with an increase in intertemporal diversification and the mean time to maturity but that the effects were not persistent. A possible explanation is that the ability of Kommuninvest to supply the sector with credit by jointly guaranteed lending during the crisis was interpreted as intertemporal diversification being unnecessary. Tax base volatility, debt-to-tax base ratio and per capita income are shown to have explanatory power when investigating the Swedish municipal sectors choice of debt maturity structure. However, some of the underlying rationale from previous research is proven unconvincing. As expected, macroeconomic variables such as interest rates are important driving factors. In addition, the governments are also less likely to undertake long-term debt when close to an election.

In conclusion, this paper highlights the importance of investigating distributional characteristics of the maturity structure in order to assess the financial risks intrinsic to debt. Even though the average time to maturity is often correlated with intertemporal diversification, it neglects important aspects of the maturity structure.

Funding This article is part of a larger research project at Örebro University titled Local Government Finance Data Analysis (LOGFIN) which has been jointly funded by Kommuninvest of Sweden AB and the Swedish innovation agency Vinnova. 


\section{Compliance with ethical standards}

Conflict of interest The author's doctorate is in part funded by Kommuninvest of Sweden AB. In addition, the author has been employed by Kommuninvest as a financial analyst/researcher since October 2013.

Ethical approval This article does not contain any studies with human participants or animals performed by the author.

Data and computer code availability The data that support the findings of this study are available from Kommuninvest of Sweden AB, but restrictions apply to the availability of these data, which were used under license for the current study, and so are not publicly available. Instructions for how other researchers can obtain the data, and all the information needed to proceed from the raw data to the results of the paper (including code) are, however, available from the authors upon reasonable request and with permission of Kommuninvest of Sweden AB.

Open Access This article is distributed under the terms of the Creative Commons Attribution 4.0 International License (http://creativecommons.org/licenses/by/4.0/), which permits unrestricted use, distribution, and reproduction in any medium, provided you give appropriate credit to the original author(s) and the source, provide a link to the Creative Commons license, and indicate if changes were made.

\section{Appendix}

See Fig. 6 and Tables 4, 5, 6, 7 and 8.

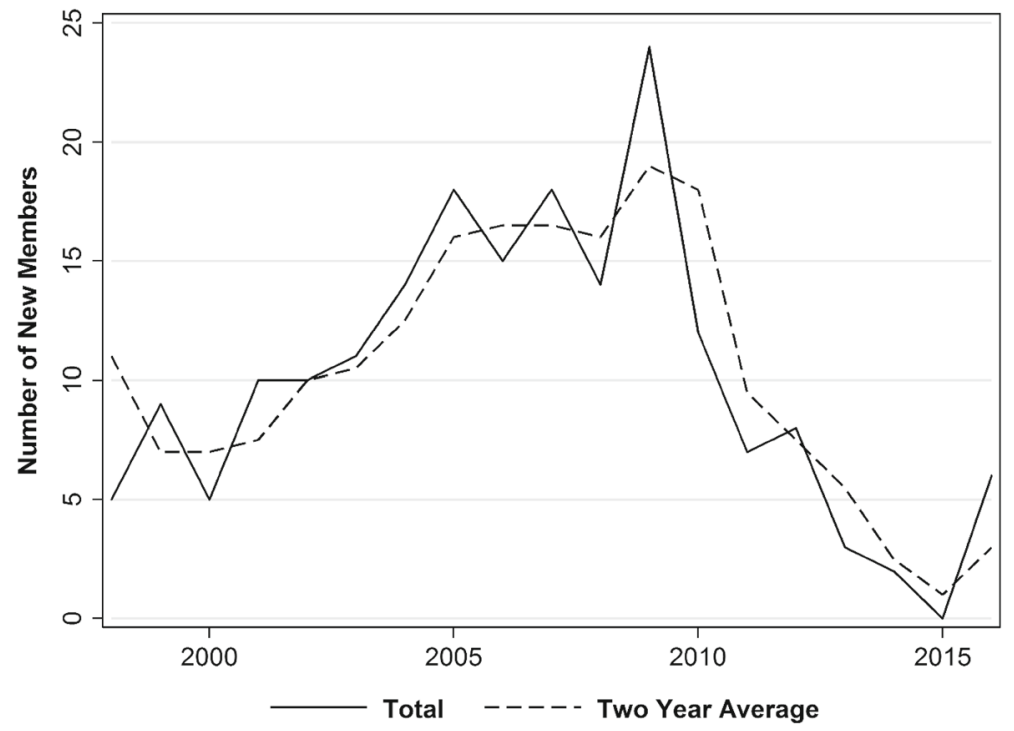

Fig. 6 Number of new Kommuninvest members per year, 1998-2016. The 2-year average is calculated over the current and previous year. Thus, the 2-year average for 2009 is the average of new Kommuninvest members joining in 2008 and 2009 
Table 4 Panel data summary statistic of measures and time to maturity

\begin{tabular}{|c|c|c|c|c|c|}
\hline Variable & Average & $\mathrm{SD}$ & Min & Max & Observations \\
\hline \multicolumn{6}{|c|}{ Time to maturity } \\
\hline Overall & 2.201 & 2.243 & 0.001 & 29.693 & $N=41,918$ \\
\hline Between & & 0.728 & 0.244 & 5.230 & $n=274$ \\
\hline Within & & 2.141 & -2.946 & 28.319 & $\overline{\mathrm{T}}=152.985$ \\
\hline \multicolumn{6}{|c|}{ Weighted mean } \\
\hline Overall & 2.210 & 1.218 & 0.025 & 15.196 & $N=41,918$ \\
\hline Between & & 0.697 & 0.781 & 5.042 & $n=274$ \\
\hline Within & & 1.043 & -1.974 & 14.297 & $\overline{\mathrm{T}}=152.985$ \\
\hline \multicolumn{6}{|c|}{ Weighted standard deviation } \\
\hline Overall & 1.779 & 1.015 & 0.000 & 14.956 & $N=41,918$ \\
\hline Between & & 0.623 & 0.000 & 4.860 & $n=273$ \\
\hline Within & & 0.821 & -2.766 & 12.274 & $\overline{\mathrm{T}}=149.165$ \\
\hline \multicolumn{6}{|c|}{ Interquartile range } \\
\hline Overall & 2.324 & 1.691 & 0.000 & 28.479 & $N=41,918$ \\
\hline Between & & 0.902 & 0.000 & 7.591 & $n=274$ \\
\hline Within & & 1.442 & -5.267 & 26.097 & $\overline{\mathrm{T}}=152.985$ \\
\hline \multicolumn{6}{|c|}{$W M I Q R(i)$} \\
\hline Overall & 3.571 & 2.131 & 0.000 & 29.103 & $N=41,918$ \\
\hline Between & & 1.352 & 0.000 & 10.252 & $n=274$ \\
\hline Within & & 1.697 & -6.681 & 25.244 & $\overline{\mathrm{T}}=152.985$ \\
\hline \multicolumn{6}{|c|}{$W M I Q R(i i)$} \\
\hline Overall & 2.253 & 1.491 & 0.000 & 27.152 & $N=41,918$ \\
\hline Between & & 0.889 & 0.000 & 7.105 & $n=274$ \\
\hline Within & & 1.219 & -4.852 & 24.459 & $\overline{\mathrm{T}}=152.985$ \\
\hline
\end{tabular}

The variable $x_{i, t}$ is decomposed into overall $(\overline{\bar{x}})$ where $\overline{\bar{x}}$ is the global mean, between $\left(\bar{x}_{i}\right)$ and within $\left(x_{i, t}-\bar{x}_{i}+\overline{\bar{x}}\right)$. This is the reason for negative minimum values for a strictly positive variable $x_{i, t}$ Information regarding the STATA command xtsum found at http://www.stata.com/manuals13/xtxtsum.pdf 
Table 5 Basic outcomes, fixed effects, January 1998 to June 2016

\begin{tabular}{|c|c|c|c|}
\hline & $\begin{array}{l}\text { Log of total portfolio } \\
\text { debt }\end{array}$ & Number of loans & Log of average loan size \\
\hline \multicolumn{4}{|l|}{ Crisis } \\
\hline Crisis & $\begin{array}{l}-0.197 * * * \\
(0.01)\end{array}$ & $\begin{array}{l}-2.806^{* * * *} \\
(0.16)\end{array}$ & $\begin{array}{l}0.067 * * * \\
(0.01)\end{array}$ \\
\hline Post-crisis & $\begin{array}{l}-0.144 * * * \\
(0.01)\end{array}$ & $\begin{array}{l}-2.533 * * * \\
(0.19)\end{array}$ & $\begin{array}{l}0.122^{* * * *} \\
(0.01)\end{array}$ \\
\hline \multicolumn{4}{|l|}{ Financial and fiscal } \\
\hline Log debt-tax base ratio & $\begin{array}{l}0.232 * * * \\
(0.00)\end{array}$ & $\begin{array}{l}1.684 * * * \\
(0.04)\end{array}$ & $\begin{array}{l}0.060^{* * * *} \\
(0.00)\end{array}$ \\
\hline $\begin{array}{l}\text { Log tax base standard } \\
\text { deviation }\end{array}$ & $\begin{array}{l}0.019 * * \\
(0.01)\end{array}$ & $\begin{array}{l}0.468 * * * \\
(0.09)\end{array}$ & $\begin{array}{l}-0.045^{* * *} \\
(0.00)\end{array}$ \\
\hline Log per capita income & $\begin{array}{l}5.584 * * * \\
(0.14)\end{array}$ & $\begin{array}{l}29.453 * * * \\
(1.93)\end{array}$ & $\begin{array}{l}0.146 \\
(0.08)\end{array}$ \\
\hline $\begin{array}{l}\text { Operating cash flow } \\
\text { ratio }\end{array}$ & $\begin{array}{l}0.001 * * * \\
(0.00)\end{array}$ & $\begin{array}{l}0.012 * * * \\
(0.00)\end{array}$ & $\begin{array}{l}0.000 \\
(0.00)\end{array}$ \\
\hline Equity-to-asset ratio & $\begin{array}{l}-0.020 * * * \\
(0.00)\end{array}$ & $\begin{array}{l}-0.141 * * * \\
(0.01)\end{array}$ & $\begin{array}{l}-0.006^{* * *} \\
(0.00)\end{array}$ \\
\hline $\begin{array}{l}\text { Surplus-to-tax revenue } \\
\text { ratio }\end{array}$ & $\begin{array}{l}0.003 * * * \\
(0.00)\end{array}$ & $\begin{array}{l}0.007 \\
(0.01)\end{array}$ & $\begin{array}{l}0.002^{* * * *} \\
(0.00)\end{array}$ \\
\hline \multicolumn{4}{|l|}{ Financial market } \\
\hline 3-month STIBOR & $\begin{array}{l}-0.005 \\
(0.00)\end{array}$ & $\begin{array}{l}0.206 * * \\
(0.07)\end{array}$ & $\begin{array}{l}-0.012 * * * \\
(0.00)\end{array}$ \\
\hline Slope & $\begin{array}{l}0.214 * * \\
(0.07)\end{array}$ & $\begin{array}{l}6.713 * * * \\
(1.02)\end{array}$ & $\begin{array}{l}0.050 \\
(0.04)\end{array}$ \\
\hline Curvature & $\begin{array}{l}0.100 \\
(0.28)\end{array}$ & $\begin{array}{l}23.289 * * * \\
(4.06)\end{array}$ & $\begin{array}{l}0.526 * * \\
(0.18)\end{array}$ \\
\hline $\begin{array}{l}\text { Negative 3-month } \\
\text { STIBOR }\end{array}$ & $\begin{array}{l}-0.105^{* * *} \\
(0.01)\end{array}$ & $\begin{array}{l}-1.128 * * * \\
(0.15)\end{array}$ & $\begin{array}{l}-0.004 \\
(0.01)\end{array}$ \\
\hline Market liquidity & $\begin{array}{l}-0.325^{* * *} \\
(0.02)\end{array}$ & $\begin{array}{l}-0.290 \\
(0.29)\end{array}$ & $\begin{array}{l}-0.090 * * * \\
(0.01)\end{array}$ \\
\hline \multicolumn{4}{|l|}{ Other } \\
\hline Election & $\begin{array}{l}-0.000 \\
(0.00)\end{array}$ & $\begin{array}{l}-0.001 \\
(0.03)\end{array}$ & $\begin{array}{l}0.002 \\
(0.00)\end{array}$ \\
\hline Year trend & $\begin{array}{l}-0.032 * * * \\
(0.00)\end{array}$ & $\begin{array}{l}0.432 * * * \\
(0.07)\end{array}$ & $\begin{array}{l}0.015^{* * * *} \\
(0.00)\end{array}$ \\
\hline Constant & $\begin{array}{l}-8.410 * * * \\
(0.65)\end{array}$ & $\begin{array}{l}-139.086^{* * *} \\
(9.29)\end{array}$ & $\begin{array}{l}16.298 * * * \\
(0.40)\end{array}$ \\
\hline$N$ & 41,349 & 41,349 & 41,349 \\
\hline$R^{2}$ (within) & 0.716 & 0.459 & 0.334 \\
\hline$\sigma_{u}$ & 0.863 & 10.288 & 0.797 \\
\hline$\sigma_{e}$ & 0.448 & 6.391 & 0.276 \\
\hline$\rho$ & 0.787 & 0.722 & 0.893 \\
\hline
\end{tabular}

Standard errors in parentheses

$* p<0.05, * * p<0.01, * * * p<0.001$ 
Table 6 Maturity structure measures, fixed-effects LAD, January 1998 to June 2016

\begin{tabular}{|c|c|c|c|c|c|}
\hline & IQ range & WMIQR (i) & WMIQR (ii) & $\mathrm{SD}$ & Mean \\
\hline \multicolumn{6}{|l|}{ Crisis } \\
\hline Crisis & $\begin{array}{l}0.229 * \\
(0.03)\end{array}$ & $\begin{array}{l}1.057 * \\
(0.15)\end{array}$ & $\begin{array}{l}1.33^{*} \\
(0.04)\end{array}$ & $\begin{array}{l}0.133 * * \\
(0.01)\end{array}$ & $\begin{array}{l}0.957 * \\
(0.03)\end{array}$ \\
\hline Post-crisis & $\begin{array}{l}-0.262 * \\
(0.02)\end{array}$ & $\begin{array}{l}0.208 * \\
(0.02)\end{array}$ & $\begin{array}{l}0.571 * \\
(0.03)\end{array}$ & $\begin{array}{l}-0.266^{*} \\
(0.03)\end{array}$ & $\begin{array}{l}0.797 * \\
(0.03)\end{array}$ \\
\hline \multicolumn{6}{|c|}{ Financial ratios and fiscal } \\
\hline $\begin{array}{l}\text { Log debt-tax } \\
\text { base ratio }\end{array}$ & $\begin{array}{l}0.068 * * \\
(0.00)\end{array}$ & $\begin{array}{l}0.106^{* * *} \\
(0.00)\end{array}$ & $\begin{array}{l}0.083 * * \\
(0.00)\end{array}$ & $\begin{array}{l}0.023 * * * \\
(0.00)\end{array}$ & $\begin{array}{l}-0.007 * * \\
(0.00)\end{array}$ \\
\hline $\begin{array}{c}\text { Log tax base } \\
\text { standard } \\
\text { deviation }\end{array}$ & $\begin{array}{l}0.123 * \\
(0.01)\end{array}$ & $\begin{array}{l}0.22 * * \\
(0.01)\end{array}$ & $\begin{array}{l}0.181 * * \\
(0.00)\end{array}$ & $\begin{array}{l}0.103 * * \\
(0.00)\end{array}$ & $\begin{array}{l}-0.025^{*} \\
(0.02)\end{array}$ \\
\hline $\begin{array}{l}\text { Log per capita } \\
\text { income }\end{array}$ & $\begin{array}{l}0.198 * \\
(0.07)\end{array}$ & $\begin{array}{l}-2.2 * \\
(0.2)\end{array}$ & $\begin{array}{l}-1.352 * \\
(0.04)\end{array}$ & $\begin{array}{l}-0.02 * \\
(0.04)\end{array}$ & $\begin{array}{l}-0.497 * \\
(0.17)\end{array}$ \\
\hline $\begin{array}{l}\text { Operating cash } \\
\text { flow ratio }\end{array}$ & $\begin{array}{l}0.001 * * * \\
(0.00)\end{array}$ & $\begin{array}{l}0.001 * * * \\
(0.00)\end{array}$ & $\begin{array}{l}0.001 * * * \\
(0.00)\end{array}$ & $\begin{array}{l}0.000 * * * \\
(0.00)\end{array}$ & $\begin{array}{l}-0.001 * * * \\
(0.00)\end{array}$ \\
\hline $\begin{array}{l}\text { Equity-to-asset } \\
\text { ratio }\end{array}$ & $\begin{array}{l}-0.014 * * * \\
(0.00)\end{array}$ & $\begin{array}{l}-0.027 * * * \\
(0.00)\end{array}$ & $\begin{array}{l}-0.005^{* * *} \\
(0.00)\end{array}$ & $\begin{array}{l}-0.01 * * * \\
(0.00)\end{array}$ & $\begin{array}{l}-0.006^{* * * *} \\
(0.00)\end{array}$ \\
\hline $\begin{array}{l}\text { Surplus-to-tax } \\
\text { revenue ratio }\end{array}$ & $\begin{array}{l}-0.005^{* * * *} \\
(0.00)\end{array}$ & $\begin{array}{l}-0.005^{* * * *} \\
(0.00)\end{array}$ & $\begin{array}{l}-0.005^{* * *} \\
(0.00)\end{array}$ & $\begin{array}{l}-0.002 * * * \\
(0.00)\end{array}$ & $\begin{array}{l}-0.004 * * \\
(0.00)\end{array}$ \\
\hline \multicolumn{6}{|l|}{ Financial market } \\
\hline $\begin{array}{l}\text { 3-month } \\
\text { STIBOR }\end{array}$ & $\begin{array}{l}-0.033 * \\
(0.01)\end{array}$ & $\begin{array}{l}-0.212 * \\
(0.02)\end{array}$ & $\begin{array}{l}-0.21 * * \\
(0.01)\end{array}$ & $\begin{array}{l}-0.074 * * \\
(0.00)\end{array}$ & $\begin{array}{l}-0.092 * \\
(0.01)\end{array}$ \\
\hline Slope & $\begin{array}{l}-1.095 * \\
(0.18)\end{array}$ & $\begin{array}{l}-5.692 * \\
(0.11)\end{array}$ & $\begin{array}{l}-4.755^{*} \\
(0.14)\end{array}$ & $\begin{array}{l}-2.651 * \\
(0.04)\end{array}$ & $\begin{array}{l}-2.327 * \\
(0.28)\end{array}$ \\
\hline Curvature & $\begin{array}{l}-6.866 \\
(0.93)\end{array}$ & $\begin{array}{l}-23.708 \\
(0.94)\end{array}$ & $\begin{array}{l}-21.149 * \\
(0.42)\end{array}$ & $\begin{array}{l}-8.219 * \\
(0.15)\end{array}$ & $\begin{array}{l}-5.207 \\
(0.82)\end{array}$ \\
\hline $\begin{array}{l}\text { Negative } \\
\text { 3-month } \\
\text { STIBOR }\end{array}$ & $\begin{array}{l}0.166^{*} \\
(0.02)\end{array}$ & $\begin{array}{l}1.002 * \\
(0.15)\end{array}$ & $\begin{array}{l}0.402 * \\
(0.01)\end{array}$ & $\begin{array}{l}0.38^{*} \\
(0.02)\end{array}$ & $\begin{array}{l}0.454^{*} \\
(0.1)\end{array}$ \\
\hline $\begin{array}{l}\text { Market } \\
\text { liquidity }\end{array}$ & $\begin{array}{l}-1.625 * \\
(0.14)\end{array}$ & $\begin{array}{l}-0.234^{*} \\
(0.11)\end{array}$ & $\begin{array}{l}-0.503 * \\
(0.02)\end{array}$ & $\begin{array}{l}0.253 * * \\
(0.01)\end{array}$ & $\begin{array}{l}-0.337 * \\
(0.08)\end{array}$ \\
\hline \multicolumn{6}{|l|}{ Other } \\
\hline Election & $\begin{array}{l}-0.023 * * \\
(0.00)\end{array}$ & $\begin{array}{l}0.012 * \\
(0.03)\end{array}$ & $\begin{array}{l}0.03 * * \\
(0.00)\end{array}$ & $\begin{array}{l}-0.081 * * \\
(0.00)\end{array}$ & $\begin{array}{l}-0.048^{* *} \\
(0.01)\end{array}$ \\
\hline Year trend & $\begin{array}{l}-0.002 * * \\
(0.00)\end{array}$ & $\begin{array}{l}-0.161^{* *} \\
(0.00)\end{array}$ & $\begin{array}{l}-0.169 * * \\
(0.01)\end{array}$ & $\begin{array}{l}-0.114^{* *} \\
(0.00)\end{array}$ & $\begin{array}{l}-0.139 * * \\
(0.00)\end{array}$ \\
\hline
\end{tabular}

Standard errors in parentheses

$* p<0.05, * * p<0.01, * * * p<0.001$ 
Table 7 Pre-2006 Kommuninvest members, fixed effects, January 1998 to June 2016

\begin{tabular}{|c|c|c|c|c|c|}
\hline & IQ range & WMIQR (i) & WMIQR (ii) & SD & Mean \\
\hline \multicolumn{6}{|l|}{ Crisis } \\
\hline Crisis & $\begin{array}{l}0.868^{* * * *} \\
(0.04)\end{array}$ & $\begin{array}{l}0.635^{* * * *} \\
(0.05)\end{array}$ & $\begin{array}{l}0.545^{* * * *} \\
(0.03)\end{array}$ & $\begin{array}{l}0.165^{* * * *} \\
(0.02)\end{array}$ & $\begin{array}{l}1.101 * * * \\
(0.03)\end{array}$ \\
\hline Post-crisis & $\begin{array}{l}0.229 * * * \\
(0.05)\end{array}$ & $\begin{array}{l}-0.163 * * \\
(0.06)\end{array}$ & $\begin{array}{l}-0.054 \\
(0.04)\end{array}$ & $\begin{array}{l}-0.192 * * * \\
(0.03)\end{array}$ & $\begin{array}{l}1.016^{* * * *} \\
(0.03)\end{array}$ \\
\hline \multicolumn{6}{|c|}{ Financial ratios and fiscal } \\
\hline $\begin{array}{l}\text { Log debt-tax } \\
\text { base ratio }\end{array}$ & $\begin{array}{l}0.081^{* * * *} \\
(0.01)\end{array}$ & $\begin{array}{l}0.181 * * * \\
(0.01)\end{array}$ & $\begin{array}{l}0.096^{* * * *} \\
(0.01)\end{array}$ & $\begin{array}{l}0.021 * * * \\
(0.00)\end{array}$ & $\begin{array}{l}-0.062 * * * \\
(0.01)\end{array}$ \\
\hline $\begin{array}{l}\text { Log tax base } \\
\text { standard } \\
\text { deviation }\end{array}$ & $\begin{array}{l}0.185^{* * * *} \\
(0.02)\end{array}$ & $\begin{array}{l}0.276^{* * * *} \\
(0.03)\end{array}$ & $\begin{array}{l}0.109 * * * \\
(0.02)\end{array}$ & $\begin{array}{l}0.120 * * * \\
(0.01)\end{array}$ & $\begin{array}{l}-0.019 * * * \\
(0.02)\end{array}$ \\
\hline $\begin{array}{l}\text { Log per capita } \\
\text { income }\end{array}$ & $\begin{array}{l}-5.663 * * * \\
(0.46)\end{array}$ & $\begin{array}{l}-4.120^{* * *} \\
(0.54)\end{array}$ & $\begin{array}{l}-4.857 * * * \\
(0.39)\end{array}$ & $\begin{array}{l}-5.978 * * * \\
(0.26)\end{array}$ & $\begin{array}{l}-12.315^{\text {*** }} \\
(0.32)\end{array}$ \\
\hline $\begin{array}{l}\text { Operating cash } \\
\text { flow ratio }\end{array}$ & $\begin{array}{l}0.001 * * * \\
(0.00)\end{array}$ & $\begin{array}{l}0.002 * * * \\
(0.00)\end{array}$ & $\begin{array}{l}0.001 * * * \\
(0.00)\end{array}$ & $\begin{array}{l}-0.000 \\
(0.00)\end{array}$ & $\begin{array}{l}-0.001 * * * \\
(0.00)\end{array}$ \\
\hline $\begin{array}{l}\text { Equity-to-asset } \\
\text { ratio }\end{array}$ & $\begin{array}{l}-0.011 * * * \\
(0.00)\end{array}$ & $\begin{array}{l}-0.023 * * * \\
(0.00)\end{array}$ & $\begin{array}{l}-0.013 * * * \\
(0.00)\end{array}$ & $\begin{array}{l}-0.007 * * * \\
(0.00)\end{array}$ & $\begin{array}{l}-0.005^{* * *} \\
(0.00)\end{array}$ \\
\hline $\begin{array}{l}\text { Surplus-to-tax } \\
\text { revenue ratio }\end{array}$ & $\begin{array}{l}-0.011 * * * \\
(0.00)\end{array}$ & $\begin{array}{l}-0.013^{* * * *} \\
(0.00)\end{array}$ & $\begin{array}{l}-0.008 * * * \\
(0.00)\end{array}$ & $\begin{array}{l}-0.006^{* * * *} \\
(0.00)\end{array}$ & $\begin{array}{l}-0.007 * * * \\
(0.00)\end{array}$ \\
\hline \multicolumn{6}{|c|}{ Financial market } \\
\hline $\begin{array}{l}\text { 3-month } \\
\text { STIBOR }\end{array}$ & $\begin{array}{l}-0.105^{* * *} * \\
(0.02)\end{array}$ & $\begin{array}{l}-0.138 * * * \\
(0.02)\end{array}$ & $\begin{array}{l}-0.073 * * * \\
(0.01)\end{array}$ & $\begin{array}{l}-0.049 * * * \\
(0.01)\end{array}$ & $\begin{array}{l}-0.083 * * * \\
(0.01)\end{array}$ \\
\hline Slope & $\begin{array}{l}-4.206^{* * * *} \\
(0.25)\end{array}$ & $\begin{array}{l}-5.187 * * * \\
(0.29)\end{array}$ & $\begin{array}{l}-3.205 * * * \\
(0.21)\end{array}$ & $\begin{array}{l}-1.993 * * * \\
(0.14)\end{array}$ & $\begin{array}{l}-2.129 * * * \\
(0.18)\end{array}$ \\
\hline Curvature & $\begin{array}{l}-19.662 * * * \\
(0.99)\end{array}$ & $\begin{array}{l}-24.761 * * * \\
(1.16)\end{array}$ & $\begin{array}{l}-14.898 * * * \\
(0.84)\end{array}$ & $\begin{array}{l}-7.823 * * * \\
(0.56)\end{array}$ & $\begin{array}{l}-7.110^{* * *} \\
(0.70)\end{array}$ \\
\hline $\begin{array}{l}\text { Negative } \\
\text { 3-month } \\
\text { STIBOR }\end{array}$ & $\begin{array}{l}0.285^{* * * *} \\
(0.04)\end{array}$ & $\begin{array}{l}0.341 * * * \\
(0.05)\end{array}$ & $\begin{array}{l}0.221 \text { *** } \\
(0.03)\end{array}$ & $\begin{array}{l}0.236 * * * \\
(0.02)\end{array}$ & $\begin{array}{l}0.324 * * * \\
(0.03)\end{array}$ \\
\hline $\begin{array}{l}\text { Market } \\
\text { liquidity }\end{array}$ & $\begin{array}{l}-0.379 * * * \\
(0.07)\end{array}$ & $\begin{array}{l}-0.614 * * * \\
(0.08)\end{array}$ & $\begin{array}{l}-0.195^{* *} \\
(0.06)\end{array}$ & $\begin{array}{l}0.042 \\
(0.04)\end{array}$ & $\begin{array}{l}0.687 * * * \\
(0.05)\end{array}$ \\
\hline \multicolumn{6}{|l|}{ Other } \\
\hline Election & $\begin{array}{l}0.033 * * * \\
(0.01)\end{array}$ & $\begin{array}{l}0.042 * * * \\
(0.01)\end{array}$ & $\begin{array}{l}0.020 * * \\
(0.01)\end{array}$ & $\begin{array}{l}0.008 \\
(0.00)\end{array}$ & $\begin{array}{l}0.050 * * * \\
(0.01)\end{array}$ \\
\hline Year trend & $\begin{array}{l}0.074 * * * \\
(0.02)\end{array}$ & $\begin{array}{l}0.063 * * \\
(0.02)\end{array}$ & $\begin{array}{l}0.111^{* * * *} \\
(0.01)\end{array}$ & $\begin{array}{l}0.117 * * * \\
(0.01)\end{array}$ & $\begin{array}{l}0.208^{* * * *} \\
(0.01)\end{array}$ \\
\hline Constant & $\begin{array}{l}32.554 * * * \\
(2.19)\end{array}$ & $\begin{array}{l}26.885 * * * \\
(2.59)\end{array}$ & $\begin{array}{l}27.580 * * * \\
(1.88)\end{array}$ & $\begin{array}{l}32.597 * * * \\
(1.26)\end{array}$ & $\begin{array}{l}64.063 * * * \\
(1.56)\end{array}$ \\
\hline$N$ & 35,199 & 35,199 & 35,199 & 34,127 & 35,199 \\
\hline$R^{2}$ (within) & 0.052 & 0.048 & 0.036 & 0.121 & 0.169 \\
\hline$\sigma_{u}$ & 1.046 & 1.345 & 0.970 & 0.796 & 1.209 \\
\hline$\sigma_{e}$ & 1.470 & 1.736 & 1.260 & 0.802 & 1.047 \\
\hline$\rho$ & 0.336 & 0.375 & 0.372 & 0.496 & 0.572 \\
\hline
\end{tabular}

Standard errors in parentheses

$* p<0.05, * * p<0.01, * * * p<0.001$ 
Table 8 Municipalities with less than 5\% points average change of Kommuninvest share during the financial crisis, fixed effects, January 1998 to June 2016

\begin{tabular}{|c|c|c|c|c|c|}
\hline & IQ range & WMIQR (i) & WMIQR (ii) & SD & Mean \\
\hline \multicolumn{6}{|l|}{ Crisis } \\
\hline Crisis & $\begin{array}{l}1.133^{* * * *} \\
(0.06)\end{array}$ & $\begin{array}{l}0.971 * * * \\
(0.06)\end{array}$ & $\begin{array}{l}0.770 * * * \\
(0.05)\end{array}$ & $\begin{array}{l}0.364 * * * \\
(0.03)\end{array}$ & $\begin{array}{l}1.403 * * * \\
(0.04)\end{array}$ \\
\hline Post-crisis & $\begin{array}{l}0.633^{* * * *} \\
(0.07)\end{array}$ & $\begin{array}{l}0.333^{* * * *} \\
(0.08)\end{array}$ & $\begin{array}{l}0.236 * * * \\
(0.06)\end{array}$ & $\begin{array}{l}0.072 \\
(0.04)\end{array}$ & $\begin{array}{l}1.345^{* * *} \\
(0.05)\end{array}$ \\
\hline \multicolumn{6}{|c|}{ Financial ratios and fiscal } \\
\hline $\begin{array}{l}\text { Log debt-tax } \\
\text { base ratio }\end{array}$ & $\begin{array}{l}0.093 * * * \\
(0.01)\end{array}$ & $\begin{array}{l}0.176^{* * *} \\
(0.01)\end{array}$ & $\begin{array}{l}0.097 * * * \\
(0.01)\end{array}$ & $\begin{array}{l}0.019 * * \\
(0.01)\end{array}$ & $\begin{array}{l}-0.009 * * * \\
(0.01)\end{array}$ \\
\hline $\begin{array}{l}\text { Log tax base } \\
\text { standard } \\
\text { deviation }\end{array}$ & $\begin{array}{l}0.058 \\
(0.03)\end{array}$ & $\begin{array}{l}0.163 * * * \\
(0.04)\end{array}$ & $\begin{array}{l}0.006 \\
(0.03)\end{array}$ & $\begin{array}{l}0.060 * * * \\
(0.02)\end{array}$ & $\begin{array}{l}-0.241^{* * *} \\
(0.02)\end{array}$ \\
\hline $\begin{array}{l}\text { Log per capita } \\
\text { income }\end{array}$ & $\begin{array}{l}-4.778 * * * \\
(0.63)\end{array}$ & $\begin{array}{l}-2.706^{* * * *} \\
(0.72)\end{array}$ & $\begin{array}{l}-2.710 * * * \\
(0.51)\end{array}$ & $\begin{array}{l}-5.947 * * * \\
(0.35)\end{array}$ & $\begin{array}{l}-10.080 * * * \\
(0.42)\end{array}$ \\
\hline $\begin{array}{l}\text { Operating cash } \\
\text { flow ratio }\end{array}$ & $\begin{array}{l}0.001 * * * \\
(0.00)\end{array}$ & $\begin{array}{l}0.004 * * * \\
(0.00)\end{array}$ & $\begin{array}{l}0.002 * * * \\
(0.00)\end{array}$ & $\begin{array}{l}0.001 * \\
(0.00)\end{array}$ & $\begin{array}{l}-0.002 * * * \\
(0.00)\end{array}$ \\
\hline $\begin{array}{l}\text { Equity-to-asset } \\
\text { ratio }\end{array}$ & $\begin{array}{l}-0.016^{* * *} \\
(0.00)\end{array}$ & $\begin{array}{l}-0.026^{* * * *} \\
(0.00)\end{array}$ & $\begin{array}{l}-0.013 * * * \\
(0.00)\end{array}$ & $\begin{array}{l}-0.012^{* * *} \\
(0.00)\end{array}$ & $\begin{array}{l}0.005^{* *} \\
(0.00)\end{array}$ \\
\hline $\begin{array}{l}\text { Surplus-to-tax } \\
\text { revenue ratio }\end{array}$ & $\begin{array}{l}-0.011 * * \\
(0.00)\end{array}$ & $\begin{array}{l}-0.018^{* * *} \\
(0.00)\end{array}$ & $\begin{array}{l}-0.012 * * * \\
(0.00)\end{array}$ & $\begin{array}{l}-0.010^{* * * *} \\
(0.00)\end{array}$ & $\begin{array}{l}-0.016^{* * *} \\
(0.00)\end{array}$ \\
\hline \multicolumn{6}{|l|}{ Financial market } \\
\hline $\begin{array}{l}\text { 3-month } \\
\text { STIBOR }\end{array}$ & $\begin{array}{l}-0.183 * * * \\
(0.02)\end{array}$ & $\begin{array}{l}-0.196^{* * * *} \\
(0.03)\end{array}$ & $\begin{array}{l}-0.091 * * * \\
(0.02)\end{array}$ & $\begin{array}{l}-0.061 \text { *** } \\
(0.01)\end{array}$ & $\begin{array}{l}-0.137 * * * \\
(0.02)\end{array}$ \\
\hline Slope & $\begin{array}{l}-4.983 * * * \\
(0.35)\end{array}$ & $\begin{array}{l}-5.781 * * * \\
(0.40)\end{array}$ & $\begin{array}{l}-2.983 * * * \\
(0.29)\end{array}$ & $\begin{array}{l}-1.882 * * * \\
(0.20)\end{array}$ & $\begin{array}{l}-2.364 * * * \\
(0.24)\end{array}$ \\
\hline Curvature & $\begin{array}{l}-21.104 * * * \\
(1.40)\end{array}$ & $\begin{array}{l}-27.399 * * * \\
(1.62)\end{array}$ & $\begin{array}{l}-14.058^{* * * *} \\
(1.15)\end{array}$ & $\begin{array}{l}-7.264 * * * \\
(0.78)\end{array}$ & $\begin{array}{l}-6.519 * * * \\
(0.95)\end{array}$ \\
\hline $\begin{array}{l}\text { Negative } \\
\text { 3-month } \\
\text { STIBOR }\end{array}$ & $\begin{array}{l}0.266^{* * * *} \\
(0.06)\end{array}$ & $\begin{array}{l}0.270 * * * \\
(0.07)\end{array}$ & $\begin{array}{l}0.171 * * * \\
(0.05)\end{array}$ & $\begin{array}{l}0.213 * * * \\
(0.03)\end{array}$ & $\begin{array}{l}0.238^{* * * *} \\
(0.04)\end{array}$ \\
\hline $\begin{array}{l}\text { Market } \\
\text { liquidity }\end{array}$ & $\begin{array}{l}-0.222 * \\
(0.10)\end{array}$ & $\begin{array}{l}-0.335^{* *} \\
(0.11)\end{array}$ & $\begin{array}{l}-0.064 \\
(0.08)\end{array}$ & $\begin{array}{l}0.344 * * * \\
(0.06)\end{array}$ & $\begin{array}{l}0.838 * * * \\
(0.07)\end{array}$ \\
\hline \multicolumn{6}{|l|}{ Other } \\
\hline Election & $\begin{array}{l}0.087 * * * \\
(0.01)\end{array}$ & $\begin{array}{l}0.101 * * * \\
(0.01)\end{array}$ & $\begin{array}{l}0.064 * * * \\
(0.01)\end{array}$ & $\begin{array}{l}0.024 * * * \\
(0.01)\end{array}$ & $\begin{array}{l}0.050^{* * *} \\
(0.01)\end{array}$ \\
\hline Year trend & $\begin{array}{l}-0.002 \\
(0.02)\end{array}$ & $\begin{array}{l}-0.027 \\
(0.03)\end{array}$ & $\begin{array}{l}0.026 \\
(0.02)\end{array}$ & $\begin{array}{l}0.098 * * * \\
(0.01)\end{array}$ & $\begin{array}{l}0.115^{* * * *} \\
(0.02)\end{array}$ \\
\hline Constant & $\begin{array}{l}28.933 * * * \\
(3.02)\end{array}$ & $\begin{array}{l}20.213 * * * \\
(3.48)\end{array}$ & $\begin{array}{l}16.993 * * * \\
(2.47)\end{array}$ & $\begin{array}{l}32.510 * * * \\
(1.70)\end{array}$ & $\begin{array}{l}53.140 * * * \\
(2.04)\end{array}$ \\
\hline$N$ & 17,603 & 17,603 & 17,603 & 16,964 & 17,603 \\
\hline$R^{2}$ (within) & 0.063 & 0.055 & 0.041 & 0.141 & 0.216 \\
\hline$\sigma_{u}$ & 0.900 & 1.210 & 0.815 & 0.786 & 1.007 \\
\hline$\sigma_{e}$ & 1.499 & 1.728 & 1.227 & 0.797 & 1.014 \\
\hline$\rho$ & 0.265 & 0.329 & 0.306 & 0.493 & 0.496 \\
\hline
\end{tabular}

Standard errors in parentheses

$* p<0.05, * * p<0.01, * * * p<0.001$ 


\section{References}

Baker MJ, Powell D, Smith TA (2016) Generalized Quantile Regression, genqreg and qregpd. STATApackage, https://ideas.repec.org/c/boc/bocode/s458157.html https://ideas.repec.org/c/boc/bocode/s45 8158.html

Barro RJ (1995) Optimal debt management. NBER Working Paper 5327

Barro RJ (1997). Optimal debt management of indexed and nominal debt. NBER Working Paper 6197

Basel Committee on Banking Supervision. (2014). Basel III: the net stable funding ratio. Bank for International Settlements

Black F, Cox J (1976) Value corporate securities: some effects of bond indenture provisions. J Finance 31:351-367

Brennan M, Schwartz E (1978) Corporate income taxes, valuation, and the problem of optimal capital structure. J Bus 51:103-114

Cestau D (2010) Why do governments choose different debt maturity structures? Revista de Ciencias Empresariales y Economía 9:37-57

Choi J, Hackbarth D, Zechner J (2018) Corporate debt maturity profiles. J Financ Econ 22:12

Cochrane JH (2015) A new structure for U.S. federal debt. In: Wessel D (ed) The \$13 trillion question: managing the U.S. government's debt. Brookings Institution Press, Washington, pp 91-146

Diamond DW (2007) Banks and liquidity creation: a simple exposition of the diamond-Dybvig model. Fed Reserve Bank Richmond Econ Q 93(2):189-200

Diamond DW, Dybvig PH (1983) Bank runs, deposit insurance, and liquidity. J Polit Econ 91(3):401-419

Diamond DW, He Z (2014) A theory of debt maturity: the long and short of debt overhang. J Finance 69(2):719-762

Diamond D, Rajan R (2011) Fear of fire sales, illiquidity seeking, and credit freezes. Quart J Econ 126(2):557-591

Financial Accounting Standards Board (1985) Employers' accounting for pensions. Statement Financ Acc Stand 87:1

Gate E, Strahan PE (2006) Banks' advantage in hedging liquidity risk: theory and evidence from the commercial paper market. J Finance 61(2):867-892

González VM (2015) The financial crisis and corporate debt maturity: the role of banking structure. J Corp Finance 35:310-328

Kolada (2018). Kolada.se. Retrieved from https://www.kolada.se/

Kommunallag (1991: 900). (2017). Dokument and lagar. Retrieved from riksdagen.se: http://www.riksdage n.se/sv/dokument-lagar/dokument/svensk-forfattningssamling/kommunallag-1991900_sfs-1991-900

Kommuninvest (2017). Retrieved from kommuninvest.se: http://www.kommuninvest.se

Leland HE (1994) Corporate debt value, bond covenants, and optimal capital structure. J Finance 49(4):1213

Litterman R, Scheinkman J (1991) Common factors affecting bond returns. J Fixed Income 1:51-61

Merton R (1973) A rational theory of option pricing. Bell J Econ Manag Sci 4:141-183

Missale A, Blanchard OJ (1994) The debt burden and debt maturity. Am Econ Rev 84(1):309-319

Modigliani F, Miller M (1958) The cost of capital, corporation finance and the theory of investment. Am Econ Rev 48(3):267-297

Modigliani F, Miller M (1963) Corporate income taxes and the cost of capital: a correction. Am Econ Rev 53(3):433-443

Myers S (1977) The determinants of corporate borrowing. J Financ Econ 5:147-175

Nelder J, Mead R (1965) A simplex method for function minimization. Comput J 7:308-313

Nordhaus WD (1975) The political business cycle. Rev Econ Stud 42:169-190

Philippon T, Schnabl P (2009) Efficient recapitalization. Working paper. NYU

Powell D (2014) Did the economic stimulus payments of 2008 reduce labor supply? Evidence from quantile panel data estimation. RAND Labor and Population Working Paper, pp. 710-713

Powell D (2015) Quantile regression with nonadditive fixed effects. RAND labor and population working paper

Powell D (2016) Quantile treatment effects in the presence of covariates. RAND labor and population working paper

Ryan RJ (2013) The evolution of asset/liability management (a summary). Research Foundation of CFA Institute, New York

Sarr A, Lybek T (2002) Measuring liquidity in financial markets. IMF working paper, WP/02/232 
Shen H (2017) Financial crises and the role of debt maturity for emerging economies. CAEPR working paper 12

Statistics Sweden (2017) Economic equalisation for local government... Retrieved from scb.se: http://www. scb.se

Sveriges Riksbank (2017) Interest and exchange rates. Retrieved from riksbank.se: http://www.riksbank.s e/en/Interest-and-exchange-rates/search-interest-rates-exchange-rates/

Sveriges Riksbank (2017). RIX. Retrieved from Riksbank.se: http://www.riksbank.se/en/Financial-stabilit y/Financial-infrastructure/Systems-in-the-Swedish-infrastructure/RIX/

The Swedish National Debt Office (2018) Historik i diagram. Retrieved from Riksgalden.se: https://www. riksgalden.se/sv/omriksgalden/statsskulden/Sveriges-statsskuld-oversikt/Historik-i-diagram/

Thierfelder F (2008) Discussion paper series 2: banking and financial studies; rollover risk in commercial paper markets and. Deutsche Bundesbank, Frankfurt am Main

\section{Affiliations}

\section{David Knezevic ${ }^{1,2}$}

1 School of Business, Örebro University, 70182 Örebro, Sweden

2 Kommuninvest of Sweden, Box 124, 70142 Örebro, Sweden 